\title{
Do Demand Curves for Currencies Slope Down? Evidence from the MSCI Global Index Change
}

\author{
Harald Hau \\ INSEAD
}

\author{
Massimo Massa \\ INSEAD
}

Joel Peress

INSEAD

\begin{abstract}
Traditional portfolio balance theory derives a downward sloping currency demand function from limited international asset substitutability. Historically, this theory enjoyed little empirical support. We provide direct evidence by examining the exchange rate effect of a major redefinition of the MSCI Global Equity Index in 2001 and 2002. The index redefinition implied large changes in the representation of different countries in the MSCI Global Equity Index and therefore produced strong exogenous equity flows by index funds. Our event study reveals that countries with a relatively increasing equity representation experienced a relative currency appreciation upon announcement of the index change. Moreover, stock markets that are upweighted (downweighted) feature a higher (lower) permanent comovement of their currency with the basket of other MSCI currencies. (JEL F21, F31, G11, G15)
\end{abstract}

To what extent do exogenous demand shocks move financial market prices? Can they propagate from one asset class to another? These are the questions we address in this article. The first question-commonly referred to as the resilience of a market-has been examined extensively for individual equity prices. ${ }^{1}$ Much less is known about the resilience of macroeconomic prices such as exchange rates. ${ }^{2}$ Yet exchange rates are particularly important and their

\footnotetext{
Johann-Ruben Schaser provided outstanding research assistance. We also thank Tamas Calderwook from MSCI for his generous help with the MSCI data. Francis Breedon and Paolo Vitale assisted us with the orderflow data. Helpful comments were provided by seminar participants at the Western Finance Association Meetings (2005), Saïd Business School (Oxford University), Brandeis University, and Humboldt University (Berlin). Send correspondence to Harald Hau, Massimo Massa, and Joel Peress, Department of Finance, Boulevard de Constance, 77305 Fontainebleau Cedex, France; telephone: (33)-1-6072-4484, (33)-1-6072-4481, (33)-1-6072-4035; fax: (33)-1-6072-4045. E-mail: harald.hau@insead.edu, massimo.massa@insead.edu, joel.peress@insead.edu.

1 We use the term "resilience" here to denote the price impact with respect to uninformative demand shocks as opposed to market depth, which refers to the price impact of general orderflow (from both informed and uninformed investors).

${ }^{2}$ It is by no means clear how resilient currencies are. On the one hand, a large literature shows that the demand for stocks slopes down (i.e., their resilience is limited). On the other hand, currencies are viewed as the most liquid
}

(C) The Author 2009. Published by Oxford University Press on behalf of The Society for Financial Studies. All rights reserved. For Permissions, please e-mail: journals.permissions@ oxfordjournals.org. doi:10.1093/rfs/hhp095

Advance Access publication December 3, 2009 
alleged misalignment is at the core of a large literature on external imbalances. Imperfect exchange rate resilience underlies the traditional portfolio approach to exchange rates, which derives a downward-sloping demand curve for foreign balances from imperfect international asset substitutability. The growing quantitative importance of equity flows has increased interest in the portfolio channel of exchange rate theory.

The second question relates to the propagation of uninformative demand shocks across markets. The traditional literature focuses on frictionless markets in which the propagation is information-based, that is, comovements in asset prices reflect comovements in their fundamental values. However, in the presence of frictions such as transaction costs, trading restrictions, or imperfect information, assets with unrelated fundamentals may comove merely because investors assign them to similar categories. For example, Barberis and Shleifer (2003) argue that investors tend to categorize assets into styles (e.g., value versus growth or small-cap versus large-cap), and allocate funds at the level of these styles rather than at the individual asset level. As they move funds across styles, they induce a correlation across the returns of assets classified into the same style, even if the cashflows of these assets are uncorrelated.Barberis, Shleifer, and Wurgler (2005) provide persuasive evidence that such style investing generates comovement among stocks, but there is no evidence to date that it can induce comovement across different asset classes such as stocks and currencies.

The correlation structure between capital flows and exchange rate movements has been the subject of much empirical research. But causal inference is hampered by a lack of clear identification. While flows may trigger exchange rate movements, flows may themselves be induced by investors' trend-chasing behavior. Similarly, though it can readily be observed that assets belonging to different classes (e.g., equity and fixed income) can move in sync or antisync, establishing a directional link from one asset class to another remains a challenge. This article examines a unique natural experiment in which the effects of flows on exchange rates can be measured for truly exogenous and uninformative portfolio flows, namely, the rebalancing of the MSCI Global Equity Index.

In December 2000, Morgan Stanley Capital International (MSCI) announced a major redefinition of its international equity indices. The new index weights would be based on the freely floating proportion of a stock's capitalization instead of the market capitalization itself. This implied a large change for the equity representation of many countries in the MSCI Global Equity Index, also referred to as MSCI ACWI (All Country World Index). Approximately US $\$ 300-\$ 350$ billion may be directly indexed to MSCI equity indices. ${ }^{3}$ The

asset class. For example, Menkhoff and Taylor (2007) estimate that currency turnover exceeds equity turnover by a factor of three in the seven largest financial centers in the world.

3 See the investment newsletter "Spotlight on: Throwing Weights Around," Hewitt Investment Group, December 2000 . 
up- or downweighting of a country or currency area therefore triggered considerable exogenous capital in- or outflow. The MSCI redefinition provides a natural experiment for the exchange rate effect of equity flows. Moreover, because demand shocks clearly originate in the equity market, it offers the opportunity to test whether they are transmitted to the currency market.

We first establish that upweighted stocks earn large excess returns around the announcement event. For example, a strategy that buys a stock upweighted by one standard deviation and sells a stock downweighted by the same amount yields an average abnormal return of $1.18 \%$ over a twelve-day window. This return opportunity is quantitatively similar for various window sizes and measures of stock returns, namely, raw or abnormal relative to an international asset pricing model, or returns denominated in U.S. dollars or in local currency. These results conform to previous studies of domestic equity index changes. They show that the equity impact of index changes carries over to international indices (i.e., that the global demand for stocks slopes down).

We then turn our attention to the currency market. We document that the announcement event caused a systematic exchange rate appreciation for (relatively) upweighted countries. Over an eight-trading-day window around the announcement event, the sixteen most upweighted currencies appreciate relative to the seventeen most downweighted countries on average by more than $2 \%$. While the exact magnitude of the effect is sensitive to the size of the event window and the estimation procedure, its qualitative nature and statistical significance is robust.

Our findings not only provide evidence that the demand for currencies slopes down, they also demonstrate that shocks to equities can propagate to currencies. Moreover, they have important implications for the current debate about international current account imbalances. If exogenous capital inflows can strengthen the domestic exchange rate, then such flows may be the source of currency overvaluation and the cause of current account deficits rather than their mere consequence. The issue of causality becomes even more important in light of the increasing quantitative significance of international equity flows over the last decade. A further implication is that any anticipation of future sterilized intervention by central banks can have an immediate exchange rate impact. ${ }^{4}$

Finally, we explore whether changes to country weights in the MSCI Global Equity Index also modify the permanent correlation structure of exchange rates. Individual stocks have been shown to comove more with an index upon their addition to the index. We find strong evidence that the same is true of currencies when their representation in a global equity index changes. We show that upweighted (downweighted) currencies tend to comove more (less) with the other currencies in the MSCI Global Equity Index.

\footnotetext{
4 An example of such an annoucement is the Plaza Accord in September 1985 when the G5 countries promised to intervene in currency markets to obtain a devalued U.S. dollar.
} 
The article is structured as follows. In the next section, we discuss the testable hypotheses. In Section 2, we review the literature. Section 3 describes the institutional background and provides summary statistics on our experiment. In Section 4, we explain the statistical methodology. The results are presented in Section 5.1 for the equity market and in Sections 5.2 and 5.3 for the currency market. Though we focus our attention on the announcement of the index redefinition, we discuss briefly in Section 5.4 how the market reacted when the index changes were implemented. Section 6 features a discussion of our findings. In Section 6.1, we examine whether the index redefinition had any impact on currencies' comovement. In Section 6.2, we discuss whether the effect on the level of exchange rates should persist. A conclusion follows.

\section{Hypotheses}

We develop two testable hypotheses that help structure our empirical analysis. The index redefinition presents a natural experiment in which the equity flows result from exogenous rebalancing needs of global index funds. This implies that these flows are not related to asymmetric information shocks or other endogenous shocks. The event study therefore allows us to assess directly whether exogenous global equity flows have an impact on domestic equity prices and exchange rates. Our analysis proceeds in two steps, starting from the equity market (Hypothesis H1) and then moving to the currency market (Hypothesis H2). Under Hypothesis H1, stocks are not perfect substitutes for one another in international equity markets - their global demand slopes down. Hence, upweighted stocks see their demand shift up and their price rise, while downweighted stocks see their demand shift down and their price fall.

\section{H1. The global demand for stocks slopes down.}

Imperfect equity substitutability implies that stock prices react to a global index redefinition. Stocks that are upweighted (downweighted) in a global index earn positive (negative) returns.

The alternative hypothesis is that of complete stock substitutability, which rules out any price effect. A nonrejection of Hypothesis $\mathrm{H} 1$ opens the possibility for the index redefinition to generate countrywide demand shocks. ${ }^{5}$ Hypothesis $\mathrm{H} 2$ investigates whether such shocks have an impact on exchange rates.

\section{H2. The demand for currencies slopes down.}

Imperfect currency substitutability implies that exchange rates react to a global index redefinition. Currencies that are upweighted (downweighted) in the index experience an exchange rate appreciation (depreciation).

\footnotetext{
5 Hypothesis H1 does not subsume Hypothesis H2. That is, observing an equity effect but no currency effect is possible, for example, if some international investors are willing to accomodate the excess demand for upweighted currencies.
} 
Under this hypothesis, exogenous shocks to the global demand for stocks aggregate at the country level and generate exogenous shocks to the demand for currencies. If currencies are not perfect substitutes for one another, then the index change can have a measurable impact on exchange rates. We emphasize that Hypothesis $\mathrm{H} 2$ does not subsume Hypothesis H1. In other words, observing a currency effect but no equity effect is possible. Indeed, if the global demand for an upweighted country's equity shifts up but local investors in that country are willing to accommodate the excess demand, then there will be no observable change in the country's equity prices. Yet, to the extent that funds do not flow out of the country, that is, local investors invest their proceeds in local securities such as nonindex stocks or fixed income assets, there will be an excess demand for the country's currency, which in turn can trigger a currency appreciation. The alternative to $\mathrm{H} 2$ states that the index redefinition does not affect exchange rates.

\section{Literature}

\subsection{Evidence on price pressure}

Our work is methodologically related to event studies of the equity price impact of (domestic equity) index changes. There is evidence that demand curves for stocks slope down. S\&P 500 index inclusions (exclusions) increase (decrease) stock prices (Garry and Goetzmann 1986; Harris and Gurel 1986; Shleifer 1986; Dillon and Johnson 1991; Beneish and Whaley 1996; Lynch and Mendenhall 1997). Chen (2006) and Onayev and Zdorovtsov (2008) find similar effects for redefinitions of Russell indices, which represent smaller stocks, and document in addition changes in stocks' liquidity. Most similar to our study, Kaul, Mehrotra, and Morck (2000) examine index reweighting for stocks in the Toronto Stock Exchange 300 index and find that upweighted stocks experience a persistent positive price effect. Greenwood (2005) studies the Nikkei 225 reweighting. Taking a portfolio approach, he shows both theoretically and empirically that limits to arbitrage are related to the risk contribution of the demand shock to the portfolio risk of an arbitrageur. Chakrabarti et al. (2005) study changes to MSCI indices as we do, but they examine equities while our focus is on currencies. They find that the rebalancing of twenty-nine MSCI country indices carried out quarterly between 1998 and 2001 leads to effects that are similar to those reported for the United States.

While the short-term price effect of index inclusions is not controversial, its persistence is debated. Shleifer (1986) argues that when a firm is added to the S\&P 500, its stock price permanently increases by $2.79 \%$. His observation is confirmed by Garry and Goetzmann (1986), who find no reversal of shortterm announcement returns, but is contradicted by Harris and Gurel (1986) and Lynch and Mendenhall (1997), who report some evidence of reversal. Massa, Tong, and Peyer (2004) help reconcile these results by showing that companies 
may offset the initial price effect of the index inclusion by issuing more shares.

While this literature has focused so far on domestic indices and the impact of their redefinitions on the equity market, we examine a global index. Beyond investigating whether domestic equity effects carry over to an international environment, the MSCI experiment allows us to study potential currency effects. Moreover, because demand shocks clearly originate in the equity market, we can provide direct evidence of their propagation to the currency market. That is, we can test whether shocks in the equity market are transmitted to the currency market. Our article is the first to provide direct evidence of such a causal linkage. As the transmission of demand shocks from the equity to the currency market induces a correlation between stocks and currenciesupweighted (downweighted) countries see both their equity and currency appreciate (depreciate) — our article also relates to the large literature on comovement. But in contrast to this literature, it displays evidence of comovement across asset classes rather than within an asset class. For example, Barberis, Shleifer, and Wurgler (2005) show that stocks included in the S\&P 500 index comove more with each other. Boyer (2004) documents a similar phenomenon when stocks switch from an S\&P/BARRA Value and Growth index to another index.

Our article also connects to a broader literature that assesses whether demand and supply shocks correlate with individual stock returns. Time series studies on block purchases and sales of stocks as well as of the trades of institutional investors have consistently uncovered evidence of temporary price pressure on individual securities conditional upon unusual demand or supply (Lakonishok, Shleifer, and Vishny 1991, 1992; Chan and Lakonishok 1993, 1995). In the international finance literature, Froot, O'Connell, and Seasholes (1998) have shown that local stock prices are sensitive to international investor flows, and that transitory inflows have a positive future impact on returns. Focusing on mutual funds, Warther (1995) and Zheng (1999) have documented that investor supply and demand effects may aggregate to the level of the stock market itself. Goetzmann and Massa (2002) show that, at daily frequency, inflows into S\&P 500 index funds have a direct impact on the stocks that are part of the index. Generally, the results in this stream of literature are contingent on implicit or explicit identification assumptions. In contrast to the aforementioned event studies, causal inference is problematic.

\subsection{Price pressure for exchange rates?}

Our study is also part of the strand of research that links exchange rate movements to currency orderflows - a measure of net buying pressure. Evans and Lyons (2002a, 2002c) document a strong contemporaneous correlation between currency returns and orderflows. The reason for this correlation, they argue, is that orderflows proxy for aggregate information flows. They develop models of 
FX trading in the presence of dispersed information that can explain over $60 \%$ of the daily Deutsche mark/U.S. dollar exchange rate movements. In a related article (Evans and Lyons 2002b), they show that trades following macroeconomic news have higher price impact. They estimate that the price impact per U.S. dollar traded is about $10 \%$ higher per news announcement in the previous hour. The MSCI Global Equity Index rebalancing that we examine here is unlikely to represent a source of macroeconomic information. It allows us to focus instead on the price impact of uninformative flows.

Uninformative flows lie at the center of the traditional portfolio approach to exchange rates. It views assets in different currencies as imperfect substitutes (Kouri 1983; Branson and Henderson 1985). This implies typically that the demand for foreign exchange balances slopes downward. Historically, the portfolio balance theory enjoyed little empirical support. ${ }^{6}$ Hau and Rey (forthcoming) provide microfoundations to the portfolio balance theory in a dynamic incomplete market framework. They derive a positive correlation between capital flows and exchange rate returns and find empirical support for the model implications in recent data. Froot and Ramadorai (2005) use a simple VAR framework to document very persistent exchange rate effects related to U.S. institutional in- and outflows. Pavlova and Rigobon (2003) and Hau and Rey (2004) use model-based identification assumptions to assess the role of capital flows for exchange rate movements. In all these studies, causal inference is contingent on the validity of the identification assumptions. The MSCI index redefinition provides a natural experiment in which the currency impact of portfolio flows can be measured for truly exogenous and uninformative flows.

The resilience of the exchange rate is also at the core of a literature on the effectiveness of central bank interventions (Edison 1993). Recent studies based on microeconomic data provide evidence that central bank interventions indeed create a price effect. Payne and Vitale (2003) show price pressure effects for interventions by the Swiss central bank. Dominquez (2003) documents a shortterm daily and intraday volatility effect related to central bank intervention. However, these studies on central bank interventions are inherently ambiguous about the nature of the exchange rate effect. Indeed, besides the traditional "portfolio effect" of the intervention, a "signaling effect" provides an alternative interpretation of the data. Central bank interventions may reveal information about the bank's future monetary policy.

\section{Institutional Background}

\subsection{MSCI and its index maintenance}

Morgan Stanley Capital International Inc. (MSCI) is a leading provider of equity (international and U.S.), fixed income, and hedge fund indices. The MSCI

\footnotetext{
${ }^{6}$ For a survey of the relevant literature, see Rogoff (1984) and Hodrick (1987).
} 
Equity indices are designed to be used by a wide variety of global institutional market participants. They are available in local currency and U.S. dollars (US\$), and with or without dividends reinvested. ${ }^{7}$ MSCI's global equity indices have become the most widely used international equity benchmarks by institutional investors. Close to two thousand organizations worldwide currently use the MSCI international equity benchmarks. Over US\$ 3 trillion of investments were benchmarked against these indices worldwide and approximately US\$ 300-350 billion are directly indexed at the time of the experiment. ${ }^{8}$ The indices with the largest international coverage are the MSCI ACWI (All Country World Index), which includes fifty developed and emerging equity markets, the MSCI World Index (based on twenty-three developed countries), the MSCI EM (Emerging Markets) Index (based on twenty-seven emerging equity markets), the MSCI EAFE (Europe, Australasia, Far East) Index (based on twenty-one developed countries outside of North America), and the MSCI Europe (based on fourteen EU countries [except Luxembourg], plus Norway and Switzerland) Index.

Over time, MSCI's methodology has evolved in order to ensure that the equity index series continue to properly represent these markets and maintain their benchmark character. The design and implementation of the index construction is based on a broad and fair market representation. In theory, a total market index, representing all listed securities in a given market, would achieve this goal. However, in practice, a total market index including all the stocks would be difficult to use as a benchmark for international investors. Therefore, MSCI builds up the indices from industry group level by restricting itself to securities that are truly replicable in global institutional portfolios of reasonable size. To maintain the goal of broad and fair market representation and reflect the evolution of the underlying markets, the indices must be reviewed regularly, which comprises inclusions and exclusions of index components. $^{9}$

MSCI commits in its published guidelines to the principles of transparency and independence from outside interests. All reviews and changes are announced at least two weeks in advance or as early as possible prior to their

\footnotetext{
7 Aggregating individual securities by different criteria, MSCI creates a broad base of indexes such as Global, Regional, and Country Equity Indexes, Sector, Industry Group and Industry Indexes, Value and Growth Indexes, Small Cap Equity Indexes, Hedged and GDP-weighted Indexes, Custom Equity Indexes, and Real Time Equity Indexes.

8 See the investment newsletter "Spotlight on: Throwing Weights Around," Hewitt Investment Group, December 2000.

9 The index maintenance can be described by three types of reviews. First, there are annual full country index reviews (at the end of May) in which MSCI reassesses systematically the various dimensions of the equity universe for all countries. Second, there are quarterly index reviews (at the end of February, August, and November), in which other significant market events are accounted for (e.g., large market transactions affecting strategic shareholders, exercise of options, share repurchases, etc.). Third, ongoing event-related changes like mergers and acquisitions, bankruptcies, or spin-offs are implemented as they occur.
} 
implementation. Only in rare cases are events announced during market hours for implementation on the same or following day. ${ }^{10}$

\subsection{The announcement process}

In February 2000, MSCI communicated that it was reviewing its weighting policy and that it was considering a move to index weights defined by the freely floating proportion of the stock value. Such free-float weights would take account of restrictions like Foreign Ownership Limits (FOLs) in different countries and therefore would better reflect the limited investibility of many stocks. Free-float weights were subsequently adopted by MSCI's competitor Dow Jones on September 18, 2000. On the next day, MSCI published a consultative article on possible changes and elicited comments from its clients. On December 1, 2000, MSCI announced that it would communicate its decision on the redefinition of the MSCI Global Equity Index on December 10, 2000. Fund managers could by then infer that MSCI's adoption of free-float weights was imminent. The second announcement on December 10, 2000, provided the timetable for the implementation of the index change in two steps and the new target for market representation was $85 \%$, up from the previous $60 \%$. To minimize the price impact of the redefinition, the equity indices would adjust $50 \%$ toward the new index on November 30, 2001, and the remaining adjustment was scheduled for May 31, 2002.

MSCI's decision was broadly in line with the previous consultative article. Only the target level of $85 \%$ was somewhat higher (by 5\%) and the implementation timetable was somewhat longer than most observers had expected. ${ }^{11}$ December 10, 2000, therefore marks the confirmation of existing market expectations. Most participants appear to have anticipated the adoption of free-float weights, at least since the first announcement 10 days earlier. An examination of transaction volumes in the Euro/U.S. dollar spot market confirms this view. We use FX transaction data previously used and documented by Breedon and Vitale (2004). ${ }^{12}$ The data consist of all electronically brokered spot transactions in both the EBS and Reuters D-2000 trading platforms on any given day from August 1, 2000, to January 24, 2001. The exact size of each transaction (in terms of U.S. dollar value) is unknown, but separate volume statistics indicate that the average FX spot transaction size in the EBS platform amounts to US\$3.14 million and is somewhat lower for trades in the Reuters system. ${ }^{13}$ In the relevant time period, EBS accounts for approximately $81 \%$ of all electronically brokered spot trades in the Euro/U.S. dollar market.

10 A more descriptive text announcement is sent out to clients for significant events like additions and deletions of constituents and changes in free float larger than US\$ 5 billion or with an impact of more than $1 \%$ of the constituent's underlying country index.

11 See again the investment newsletter "Spotlight on: Throwing Weights Around," Hewitt Investment Group, December 2000.

12 We thank Francis Breedon and Paolo Vitale for generously sharing the data.

13 See Table 3 in Breedon and Vitale (2004). 


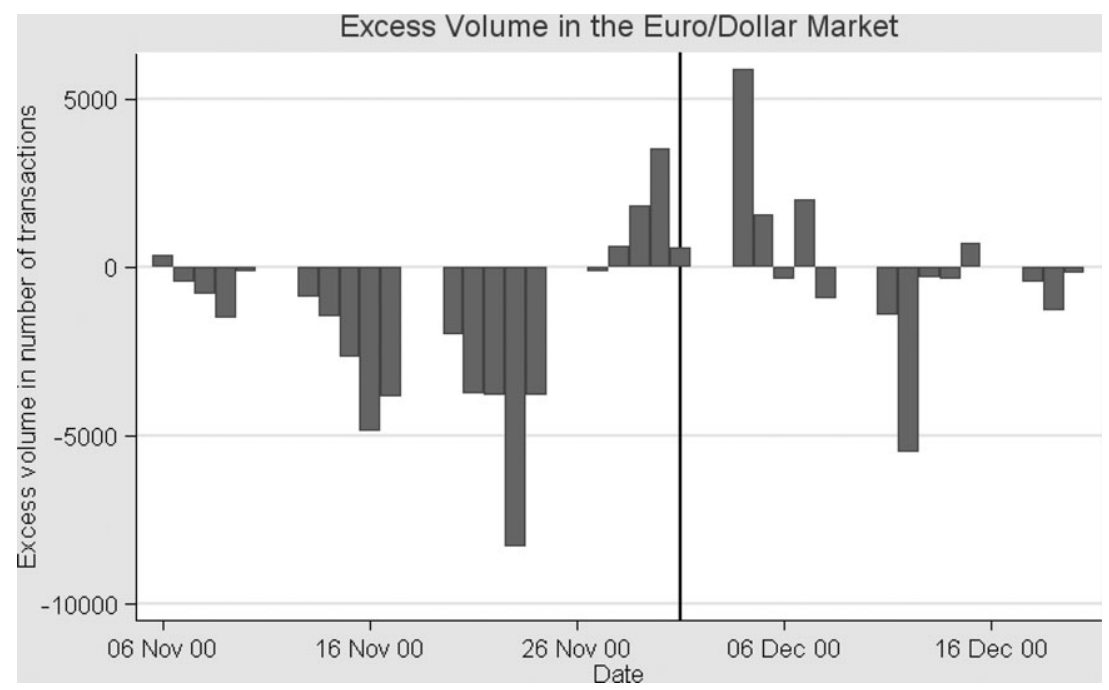

Figure 1

Plotted is the daily transaction volume in the Euro/U.S. dollar spot market around December 1, 2000, net of day-of-the-week effects

The volume data consist of the daily number of transactions in both the EBS and Reuters D-2000 spot trading platforms (see Breedon and Vitale 2004). The average trading volume (in terms of number of transactions) for the same day of the week over the six-month period from $01 / 08 / 2000$ to $24 / 01 / 2001$ is subtracted from the trading volume on a given day. The black vertical line marks the first announcement day (December 1, 2000). Trading volume peaks on the first trading day (December 4, 2000) that follows it but does not on the first trading day after the second announcement (December 11, 2000).

Figure 1 shows total excess trading volume (by number of transactions net of day-of-the-week effects) for a 1-month window around December 1, 2000. We obtain excess volume by subtracting from the gross number of transactions on any given day the average number of transactions for the same day of the week over the sample period. The FX volume on Friday, December 1, 2000 (just before the MSCI announcement), is characterized by a small positive excess volume of 574 transactions. More striking is the trading volume on the first working day following the announcement, namely, Monday, December 4. It exceeds the average Monday trading volume by 5,911 transactions. By contrast, trading volume on Monday, December 11, the first working day after the second announcement, was below average. The transaction volumes indicate that December 1, 2000, was the relevant news event and we refer to this first date as the relevant announcement date. But information leakages even prior to December 1, 2000, are plausible, as well. The foreign exchange abnormal spot volume did also peak on November 30, 2000, with a total excess volume of 3,545 transactions.

\subsection{The new index methodology}

The new methodology differs from the previous equity index definition in two aspects. First, stock selection is based on freely floating capital as opposed 
to market capitalization. Second, the market representation is enhanced in the new index. MSCI defines the free float of a security as the proportion of shares outstanding that is available for purchase by international investors. In practice, limitations on the investment opportunities of international institutions are common due to so-called "strategic holdings" by either public or private investors. Given that disclosure requirements generally do not permit a clear identification of "strategic" investments, MSCI labels shareholdings by classifying investors as strategic and nonstrategic. Freely floating shares include those held by households, investment funds, mutual funds and unit trusts, pension funds, insurance companies, social security funds, and security brokers. The non-free-float shares include those held by governments, companies, banks (excluding trusts), principal officers, board members, and employees. Non-freefloat is also defined in terms of foreign ownership restrictions. Such foreign ownership limits (FOLs) can come from law, government regulations, company by-laws, and other authoritative statements. MSCI free float adjusts the market capitalization of each security using a factor referred to as the foreign inclusion factor (FIF). For securities subject to FOLs, the FIF is equal to the lesser of the FOL (rounded to the closest $1 \%$ increment) and the free float available to foreign investors (rounded up to the closest 5\% increment above $15 \%$ and to the closest $1 \%$ below a $15 \%$ free float). Securities with a FIF of less than $15 \%$ across all share classes are generally not eligible for inclusion in the MSCI indices. $^{14}$

The second goal of the equity index modification was an enhanced market representation. In its new indices, MSCI targets a free-float-adjusted market representation of $85 \%$ within each industry and country, compared to the $60 \%$ share based on market capitalization in the old index. Because of differences in industry structure, the $85 \%$ threshold may not be uniformly achieved. Moreover, the occasional over- and under-representation of industries may also imply that the aggregate country representation may deviate from the $85 \%$ target. ${ }^{15}$

The overall index rebalancing effect is illustrated in Figure 2, which plots the percentage change in index weight for each country in the Global Equity Index (ACWI) as a function of the initial weight. The percentage weight change $\Delta w_{i}$ is expressed in percentage terms (relative to the mid-point) as

$$
\Delta w_{i}=\frac{w_{i}^{n}-w_{i}^{o}}{\frac{1}{2}\left(w_{i}^{n}+w_{i}^{o}\right)},
$$

where $w_{i}^{o}$ and $w_{i}^{n}$ represent, respectively, the old and new index weight of country $i$. Normalizing by the average country weight allows us to adjust

14 Exceptions to this general rule are made only in significant cases, where exclusion of a large company would compromise the index's ability to fully and fairly represent the characteristics of the underlying market.

15 MSCI's bottom-up approach to index construction may lead to a large company in an industry not being included in the index, while a smaller company from a different industry might be included. 


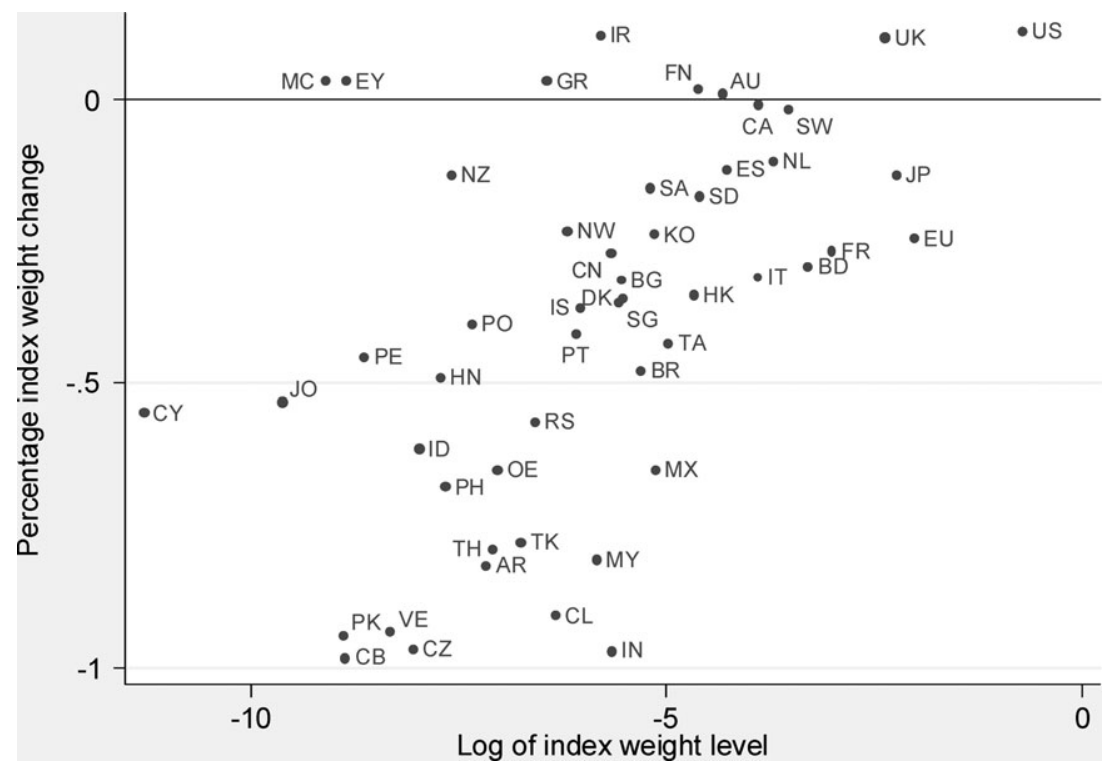

Figure 2

The percentage weight change of a country in the MSCI Global Equity Index (ACWI) is plotted against the log level of the country's weight prior to the index redefinition

The fifty index countries are Argentina (AR), Australia (AU), Brazil (BR), Canada (CA), Chile (CL), China (CN), Colombia (CB), Czech Republic (CZ), Denmark (DK), Egypt (EY), Hong Kong (HK), Hungary (HN), India (IN), Indonesia (ID), Israel (IS), Japan (JP), Jordan (JO), Korea (KO), Malaysia (MY), Mexico (MX), Morocco (MC), New Zealand (NZ), Norway (NW), Pakistan (PK), Peru (PE), Philippines (PH), Poland (PO), Russia (RS), Singapore (SG), South Africa (SA), Sri Lanka (CY), Sweden (SD), Switzerland (SW), Taiwan (TA), Thailand (TH), Turkey (TK), United Kingdom (UK), United States (US), Venezuela (VE), and the Euro area (EU). The Euro area aggregate is composed of eleven countries, namely Austria (OE), Belgium (BG), Finland (FN), France (FR), Germany (BD), Greece (GR), Ireland (IR), Italy (IT), Netherlands (NL), Portugal (PT), and Spain (ES).

for the size of the country's economy. ${ }^{16}$ Figure 2 shows that most countries were in fact downweighted, and many by a considerable amount in percentage terms. The most important beneficiaries of the new methodology are the United States, the United Kingdom, and Ireland, with percentage weight increases of $12 \%, 10.9 \%$, and $11.4 \%$, respectively. The main losers in percentage terms are Columbia with a decrease by $-98.3 \%$, India by $-97.1 \%$, and the Czech Republic by $-96.7 \%$. In the subsequent analysis, we assign countries to groups according to their weight change. To simplify the exposition, we refer to countries with the largest (smallest) weight change as "upweighted (downweighted) countries," respectively, even though some "upweighted countries" are actually downweighted.

16 The weight level is commensurate to the size of a country's economy. Smaller countries experience smaller absolute weight changes. Yet the impact on their currency is unlikely to be smaller. Furthermore, there is no need to deduct from country weights the weight assigned to the United States though exchange rates are calculated against the U.S. dollar since our tests are based on how exchange rates move relative to one another (i.e., a reweighting of the United States affects all countries in a similar way). We confirm in section 6.3 that our results are robust to the use of alternative measures of the weight change. 
The initial sample consists of the fifty countries in the MSCI ACWI. ${ }^{17} \mathrm{We}$ exclude the United States as the U.S. dollar constitutes our reference currency. We also remove Argentina, Brazil, and Turkey because these countries experienced a major currency crisis before or during the period of our analysis. Since the eleven countries in the Euro zone share one common exchange rate, we aggregate these observations into one so that the old (new) weight equals the sum of the eleven country weights in the old (new) index. The final sample consists of thirty-six countries with exchange rate data, of which ten are from developed and twenty-six are from emerging markets. Three countries, namely China, Malaysia, and Hong Kong, maintained their currencies pegged to the U.S. dollar. We therefore excluded these three currencies from our sample, which leaves us with thirty-three countries and 2,436 stocks. ${ }^{18}$ Cross-sectional summary statistics for the weight changes of countries and stocks are reported in Table 1. The table also provides summary statistics on the cross-sectional exchange rate and stock returns for the announcement event windows. Because of the predominant role of the U.S. dollar in the global MSCI index, we express all exchange rate changes in U.S. dollars per local currency. Generally, we denote by $e_{i t}$ the value of currency $i$ at date $t$. An appreciation of currency $i$ against the U.S. dollar implies $\Delta e_{i t}>0$. All exchange rate and stock returns data were obtained from Datastream. Daily exchange rate returns are based on log exchange rate changes since the previous (end of the day) London price fixing.

\section{Statistical Methodology}

An index fund should rebalance its portfolio close to the implementation of the index change. This timing will minimize the tracking error relative to the valid benchmark. On the other hand, a possible price impact justifies a more gradual rebalancing toward the new index. Risk arbitrageurs are likely to anticipate the price impact of index trackers and front-run their reallocation. As in most studies, we focus our attention on the announcement event (but also discuss the implementation events) and use a symmetric window of a few days around it. This is the most appropriate method to capture front-running effects. We experiment with both a short window of six trading days and a longer window of twelve trading days. Generally, we cannot exclude the possibility that a large proportion of any possible exchange rate effect occurs outside our chosen event

17 The 50 index countries are: Argentina, Australia, Brazil, Canada, Chile, China, Colombia, Czech Republic, Denmark, Egypt, Hong Kong, Hungary, India, Indonesia, Israel, Japan, Jordan, Korea, Malaysia, Mexico, Morocco, New Zealand, Norway, Pakistan, Peru, Philippines, Poland, Russia, Singapore, South Africa, Sri Lanka, Sweden, Switzerland, Taiwan, Thailand, Turkey, United Kingdom, United States, Venezuela, and the 11 Euro area countries, namely Austria, Belgium, Finland, France, Germany, Greece, Ireland, Italy, Netherlands, Portugal, and Spain.

18 We check that our results are robust to the inclusion of the three countries that experienced a currency crisis or of the three countries with pegged currencies. 
Table 1

Summary statistics

Obs. Mean S.D. Min Max

Scaled weights

$\Delta w_{i}=\frac{w_{i}^{n}-w_{i}^{o}}{\frac{1}{2}\left(w_{i}^{n}+w_{i}^{o}\right)}$

Country weight change

$\Delta w_{i}^{F X}=\frac{w_{i}^{n}-w_{i}^{o}}{\operatorname{Vol}_{i}^{F X}}$

(i) Percent (elative to mean)

$33-0.4269$

0.3385

$-0.9825$

0.1086

$\Delta w_{i}^{S P}=\frac{w_{i}^{n}-w_{i}^{o}}{\operatorname{Vol}_{i}^{S P}}$

(ii) Scaled by total FX volume

$27-0.2910$

0.3939

$-1.6812$

0.0688

(iii) Scaled by FX spot volume

27

$-0.6124$

0.7626

$-3.3807$

0.2549

$\Delta w_{i j}=\frac{w_{i j}^{n}-w_{i j}^{o}}{\frac{1}{2}\left(w_{i j}^{n}+w_{i j}^{o}\right)}$

Stock weight change (percent)

2436

$-0.1045$

1.1778

$-2.0000$

2.0000

Currency market

$\Delta e_{i}^{6}$
$\Delta e_{i}^{12}$
$O F_{t}$

U.S. dollar exchange rate return

U.S. dollar exchange rate return

1.2986

2.2191

$-2.0783$

5.4302

12

1.422

1.127

$-0.334$

2.658

Equity market

$\Delta r_{i j}^{6}$
$\Delta r_{i j}^{12}$
$\Delta r_{i j}^{6}$

U.S. dollar raw stock return

$\begin{array}{ll}78.6483 & -117.7486\end{array}$

U.S. dollar abnormal stock return

U.S. dollar raw stock return

U.S. dollar abnormal stock return

Local currency abnormal

$\begin{array}{llll}0.83335 & 7.7611 & -121.154 & 40.6059\end{array}$

$\Delta r_{i j}^{12}$ stock return

2362

0.0863

$7.4969-114.3833$

Local currency

2.5729

10.7093

$-102.5828$

46.5046

raw stock return

Local currency abnormal

2362

0.1310

9.7947

$-99.3108$

44.6548

For the sample countries, we report summary statistics on different measures of country index reweighting, $\Delta w_{i}$, on U.S. dollar exchange rate return, $\Delta e_{i}$, and individual stock returns, $\Delta r_{i j}$, for stock $j$ trading in country $i$. The country weight change $w_{i}^{n}-w_{i}^{o}$ is scaled by (i) the mean between new and old country weights $\frac{1}{2}\left(w_{i}^{n}+w_{i}^{o}\right)$, (ii) the total FX market volume in currency $i, \operatorname{Vol}_{i}^{F X}$ or (iii) the FX spot market volume, $\operatorname{Vol}_{i}^{S P}$. In addition to spot trading volume, total FX volume includes outright forward contracts and swap contracts. Currency trading volume is available in the BIS currency market survey for April 2001 for a subsample of twenty-seven currencies. For stock returns, we report both raw and abnormal (log) returns denominated in either the local currency or U.S. dollars. Abnormal stocks returns are computed for each stock using a two-factor international asset pricing model that includes both domestic and global market risk (see the text for details). Exchange rates, index, and individual stock returns are log returns in percentage points and measured over a symmetric 6- and 12-tradingday window (marked by the superscripts 6 and 12, respectively) around the announcement day of the index reweighting (December 1, 2000). The exchange rate statistics exclude Argentina, Brazil, and Turkey because they experienced a major currency crisis around the time of our analysis, as well as China, Hong Kong, and Malaysia because their currencies were pegged to the U.S. dollar. The permanent constituents are all the stacks that belonged to the index before and after the experiment (i.e., not added or dropped).

window. ${ }^{19}$ The qualitative nature of our evidence is therefore more relevant than its quantitative aspect.

\subsection{Equity market}

We use a standard least squares approach to check whether upweighted (downweighted) stocks earn positive (negative) returns. Specifically, we regress

19 Any information leakage about the index change prior to the event window implies that we tend to underestimate the equity and exchange rate effects. Estimates are therefore only lower bounds for the full effect of the index change. 
individual stock returns on their weight change and a constant:

$$
\Delta r_{i j}=\alpha_{0}+\alpha_{1} \Delta w_{i j}+\mu_{i j}
$$

where $\Delta r_{i j}$ is the return on stock $j$ (which trades in country $i$ ) over the announcement window and $\Delta w_{i j}$ is the change in its index weight, defined as above, $\Delta w_{i j}=2\left(w_{i j}^{n}-w_{i j}^{o}\right) /\left(w_{i j}^{n}+w_{i j}^{o}\right)$. The coefficient $\alpha_{1}$ captures the systematic effect of weight changes on stock returns, while the constant $\alpha_{0}$ identifies changes that are common to all stocks over the window. Under Hypothesis H1, its estimate $\hat{\alpha}_{1}$ should be significantly positive. We employ various measures of stock returns. We start with raw stock returns, denominated both in the local currency (the currency of country $i$ ) to factor out currency effects and in U.S. dollars. Then we use abnormal stock returns, based on a two-factor international asset pricing model that includes both domestic and global market risk. Specifically, we regress individual stock returns on a constant, the return on a domestic market index, and the return on a global index:

$$
r_{i j t}=\beta_{i j 0}+\beta_{i j D} \times r_{D i t}+\beta_{i j W} \times r_{W t}+\varepsilon_{i j t},
$$

where $r_{i j t}$ is the $(\log )$ return on day $t$ on stock $j$ in country $i, r_{D i t}$ is the return on country $i$ 's domestic market index (the Datastream index for country $i$ ) on day $t$, and $r_{W t}$ is the return on the global market index (the Datastream world index) on day $t .{ }^{20}$ The estimated coefficients are a constant $\beta_{i j 0}$, stock $j$ 's loading on the domestic market index $\beta_{i j D}$, and its loading on the global market index $\beta_{i j W}$. The regressions are estimated using daily returns over a pre-announcement window of one hundred trading days from $t=-107$ to $t=-8$ (from July 4, 2000, to November 21, 2000). Abnormal returns are then calculated over the announcement window as

$$
r_{i j t}-\left(\beta_{i j 0}+\beta_{i j D} \times r_{D i t}+\beta_{i j W} \times r_{W t}\right)
$$

for $t=-2$ to $t=+3$ for a six-day window or for $t=-5$ to $t=+6$ for a twelve-day window. As with raw returns, we estimate abnormal stock returns both in local currency and in U.S. dollars. To obtain abnormal stock returns in local currency (U.S. dollars), we use returns on the stock, the domestic index, and the global index denominated in the local currency (U.S. dollars). We report standard errors adjusted using White's correction for heteroskedasticity, as well as clustered around countries.

\subsection{Currency market}

Given the large cross-section of stocks, a simple least-squares approach yields accurate estimates of the slope of the demand for stocks, $\alpha_{1}$. This is no longer the

20 To avoid any "circularity" in our argument, we do not use MSCI indices to compute abnormal returns. Unreported results based on MSCI indices are analogous. 
case when we turn to exchange rates. We therefore assess the relation between country weight changes and currency returns using three different tests. First, we carry out a nonparametric Fisher test. This test examines whether the ranking of the percentage weight change $\Delta w_{i}$ is related to the ranking of the exchange rate change $\Delta e_{i}^{s}$ over the event window, where $s$ denotes the window length. An advantage of the Fisher test is that it represents an exact test and is therefore particularly appropriate for small samples. Its null hypothesis is a nonzero correlation between the currencies return over the event window and the weight change. A problem with the test is that such a nonzero correlation might also exist outside the event period in normal times. If, for example, exchange rate correlations among upweighted exchange rates are systematically different from exchange rate correlations among downweighted currency, then the null hypothesis of the Fisher test could be rejected over any arbitrary time interval. In this case, the Fisher test provides necessary but not sufficient evidence to claim any event-specific effect. Unfortunately, we find evidence of such correlation clustering in the dimension of the country weight changes. Currency pairs of upweighted countries comove more than currency pairs, consisting of one upand one downweighted country (we describe the evidence for this phenomenon in the next section). The null hypothesis of the Fisher test may therefore be too general for the problem in hand. We need a model specification that identifies an event-specific effect against the background of an arbitrary contemporaneous correlation structure of all exchange rates.

Our second test addresses the issue of correlation clustering by explicitly accounting for the covariance structure of all currencies. To obtain reliable covariance estimates, we combine the event sample with historical exchange rate data. The historical data cover weekly exchange rate returns from July 1 , 1996, to July 1, 2000. The weekly returns are measured from the Monday closing price to the next Monday closing price. We define a time dummy $D_{t}$, which equals one for the week with the announcement date (December 1, 2000) and zero for the historical data period. The weekly exchange rate return $\Delta e_{i t}$ is regressed on the demeaned scaled weight change $\Delta \bar{w}_{i}$ for currency $i$ (defined as $\left.\Delta \bar{w}_{i}=\Delta w_{i}-\frac{1}{N} \sum_{n=i}^{N} \Delta w_{i}\right)$ interacted with the time dummy $D_{t}$. Formally, we have

$$
\Delta e_{i t}=\alpha_{0}+\alpha_{1} D_{t}+\alpha_{2}\left(\Delta \bar{w}_{i} \times D_{t}\right)+\mu_{i t}
$$

We report coefficient estimates $\hat{\alpha}_{1}$ and $\widehat{\alpha}_{2}$ under both OLS and a panelerror-adjusted procedure. In the latter, the coefficients are estimated using a Prais-Winsten regression and the standard errors are adjusted by assuming that the disturbances are heteroskedastic and contemporaneously correlated across panels and time (which we refer to as a "general covariance structure"). The coefficient $\alpha_{2}$ captures the systematic effect of the weight change on the exchange rate, while the coefficient $\alpha_{1}$ reflects U.S. dollar specific effects common to all currencies. Hypothesis $\mathrm{H} 2$ is consistent with a significantly positive $\hat{\alpha}_{2}$. 
Our third test pushes the analysis of currencies one step further. It accounts for the possibility that currency trades induced by the index redefinition may not be spread uniformly over the event window, so identifying the days on which they are more intense can improve the power of our tests. It is plausible that arbitrageurs take positions simultaneously in all currencies. In that case, above average trading in one currency can serve as a proxy for the "speculative intensity" common to all currencies.

Euro/U.S. dollar orderflow statistics obtained from Breedon and Vitale (2004) allow us to carry out this analysis. These data consist of the number of daily buy- minus sell-initiated orders in the two important interdealer trading systems EBS and Reuters D-2000 over a window ranging from August 2000 to January 2001 (i.e., a period that straddles the announcement). The daily frequency of the orderflow data allows us to distinguish trading days characterized by particularly large U.S. dollar purchases within the event window. The U.S. equity market was upweighted in the MSCI Global Equity Index relative to all other markets, including the Euro-denominated equity markets. We expect therefore to observe positive orderflows $O F_{t}$ for days of strong speculative trading induced by the index rebalancing. For the event window, we define $\overline{O F}_{t}$ as the demeaned daily FX orderflow and assume it provides an appropriate intertemporal measure of speculative intensity common to all currency markets. We interact orderflow with the demeaned cross-sectional weight change to generate a panel structure with both daily and country variation. This allows us to repeat the multivariate regression on daily data. We use again a general covariance structure across all the exchanges and time to control for correlation clustering. The time dummy $D_{t}$ now equals one for each day around the announcement date and zero otherwise. In particular, we estimate the linear regression:

$$
\begin{aligned}
\Delta e_{i t}= & \alpha_{0}+\alpha_{1} D_{t}+\alpha_{2}\left(\Delta \bar{w}_{i} \times D_{t}\right)+\alpha_{3}\left(\overline{O F}_{t} \times D_{t}\right) \\
& +\alpha_{4}\left(\Delta \bar{w}_{i} \times \overline{O F}_{t} \times D_{t}\right)+\mu_{i t} .
\end{aligned}
$$

Under Hypothesis H2, the estimates of $\hat{\alpha}_{2}$ and/or $\hat{\alpha}_{4}$ should be significantly positive. The coefficients $\alpha_{1}$ and $\alpha_{3}$ again capture U.S. dollar-specific effects common to all currencies.

\section{Results}

\subsection{Equity market}

Table 2 reports estimates of cross-sectional least-squares regressions of individual stock returns on individual stock weight changes. In panel A, stock returns are measured in local currency in order to exclude any exchange rate effect. We therefore look at excess returns from the perspective of a local investor. In panel B, we measure stock returns in U.S. dollars. We report standard errors corrected for heteroskedasticity using White's adjustment, as well as clustered by country. Table 2 shows strongly significant estimates of $\alpha_{1}$ whether returns are raw or abnormal and whether they are denominated in the local currency or U.S. dollars. 
Table 2

Individual stock return regression

Panel A: Individual stock returns in local currency

$\Delta r_{i j}=\alpha_{0}+\alpha_{1} \Delta w_{i j}+\mu_{i j}$

\begin{tabular}{|c|c|c|c|c|c|c|c|c|}
\hline \multirow[b]{2}{*}{ Window size } & \multicolumn{2}{|c|}{$\begin{array}{c}\text { Raw returns } \\
\text { OLS }\end{array}$} & \multicolumn{2}{|c|}{$\begin{array}{c}\text { Abnormal returns } \\
\text { OLS }\end{array}$} & \multicolumn{2}{|c|}{$\begin{array}{l}\text { Raw returns } \\
\text { OLS clustered }\end{array}$} & \multicolumn{2}{|c|}{$\begin{array}{c}\text { Abnormal returns } \\
\text { OLS clustered }\end{array}$} \\
\hline & $\begin{array}{l}(1) \\
6 \text { Days }\end{array}$ & $\begin{array}{c}(2) \\
12 \text { Days }\end{array}$ & $\begin{array}{l}\text { (3) } \\
6 \text { Days }\end{array}$ & $\begin{array}{c}(4) \\
12 \text { Days }\end{array}$ & $\begin{array}{l}\text { (5) } \\
6 \text { Days }\end{array}$ & $\begin{array}{c}(6) \\
12 \text { Days }\end{array}$ & $\begin{array}{l}(7) \\
6 \text { Days }\end{array}$ & $\begin{array}{c}(8) \\
12 \text { Days }\end{array}$ \\
\hline Constant & $\begin{array}{l}0.894^{* * *} \\
(0.157)\end{array}$ & $\begin{array}{l}2.716^{* * * *} \\
(0.216)\end{array}$ & $\begin{array}{c}0.124 \\
(0.154)\end{array}$ & $\begin{array}{c}0.189 \\
(0.201)\end{array}$ & $\begin{array}{c}0.894^{* *} \\
(0.427)\end{array}$ & $\begin{array}{l}2.716^{* * *} \\
(0.849)\end{array}$ & $\begin{array}{c}0.124 \\
(0.209)\end{array}$ & $\begin{array}{c}0.189 \\
(0.394)\end{array}$ \\
\hline$\Delta w_{i j}$ & $\begin{array}{l}0.565^{* * *} \\
(0.152)\end{array}$ & $\begin{array}{l}1.303^{* * *} \\
(0.205)\end{array}$ & $\begin{array}{c}0.327^{* *} \\
(0.150)\end{array}$ & $\begin{array}{l}0.502^{* * *} \\
(0.187)\end{array}$ & $\begin{array}{l}0.565^{* *} \\
(0.270)\end{array}$ & $\begin{array}{l}1.303^{* *} \\
(0.544)\end{array}$ & $\begin{array}{r}0.327^{*} \\
(0.165)\end{array}$ & $\begin{array}{c}0.502^{* *} \\
(0.243)\end{array}$ \\
\hline $\begin{array}{l}\text { Obs. } \\
R^{2}\end{array}$ & $\begin{array}{l}2412 \\
0.0074\end{array}$ & $\begin{array}{l}2410 \\
0.0206\end{array}$ & $\begin{array}{l}2362 \\
0.0027\end{array}$ & $\begin{array}{l}2362 \\
0.0037\end{array}$ & $\begin{array}{l}2412 \\
0.0074\end{array}$ & $\begin{array}{l}2410 \\
0.0206\end{array}$ & $\begin{array}{l}2362 \\
0.0027\end{array}$ & $\begin{array}{l}2362 \\
0.0037\end{array}$ \\
\hline \multicolumn{9}{|c|}{ Panel B: Individual stock returns in U.S. dollars } \\
\hline Constant & $\begin{array}{l}1.960^{* * *} \\
(0.159)\end{array}$ & $\begin{array}{l}3.919^{* * * *} \\
(0.217)\end{array}$ & $\begin{array}{r}0.289^{*} \\
(0.153)\end{array}$ & $\begin{array}{c}0.303 \\
(0.200)\end{array}$ & $\begin{array}{c}0.020 \\
(0.426)\end{array}$ & $\begin{array}{c}0.039 \\
(0.727)\end{array}$ & $\begin{array}{c}0.289 \\
(0.238)\end{array}$ & $\begin{array}{c}0.303 \\
(0.473)\end{array}$ \\
\hline$\Delta w_{i j}$ & $\begin{array}{l}0.582^{* * *} \\
(0.152)\end{array}$ & $\begin{array}{l}1.357^{* * *} \\
(0.204)\end{array}$ & $\begin{array}{l}0.321^{* *} \\
(0.151)\end{array}$ & $\begin{array}{l}0.513^{* * *} \\
(0.188)\end{array}$ & $\begin{array}{l}0.582^{* *} \\
(0.221)\end{array}$ & $\begin{array}{l}0.136^{* * * *} \\
(0.481)\end{array}$ & $\begin{array}{l}0.321^{* *} \\
(0.158)\end{array}$ & $\begin{array}{c}0.513^{* *} \\
(0.248)\end{array}$ \\
\hline Obs. & 2412 & 2410 & 2362 & 2362 & 2412 & 2410 & 2362 & 2362 \\
\hline$R^{2}$ & 0.0076 & 0.0220 & 0.0026 & 0.0037 & 0.0076 & 0.0220 & 0.0026 & 0.0038 \\
\hline
\end{tabular}

We perform a cross-sectional least squares regression of the return of stock $j$ in country $i$ on the stock's percentage weight change in the MSCI Global Equity Index (ACWI), $\Delta w_{i j}=\frac{w_{i j}^{n}-w_{i j}^{o}}{\frac{1}{2}\left(w_{i j}^{n}+w_{i j}^{o}\right)}$. Panel A reports estimates based on stock returns denominated in the local currency of country $i$, and panel B estimates based on stock returns denominated in U.S. dollars. Raw and abnormal stock returns are measured (in percentage points) over a sixand twelve-day event window around the announcement day of the index reweighting (December 1, 2000). Abnormal returns in local currency and U.S. dollars are computed for each stock using a two-factor international asset pricing model that includes both domestic and global market risk (see the text for details). We report in parentheses robust standard errors adjusted for heteroskedasticity using White's correction ("OLS" column) and clustered by country ("OLS Clustered" column). We indicate by *, ${ }^{* *}$, and ${ }^{* * *}$ significance at the $5 \%, 3 \%$, and $1 \%$ level, respectively.

This effect is also quantitatively large. A strategy that buys an upweighted stock by one standard deviation and sells a downweighted stock by the same amount yields an average abnormal return of $1.18 \%(=1.18 \times 2 \times 0.502)$ over a twelveday window. This return opportunity is quantitatively similar for the six-day window and whether returns are denominated in U.S. dollars or local currency.

Thus, upweighted stocks experience excess returns around the announcement event, consistent with Hypothesis H1. These results conform to previous studies of domestic equity index changes. They show that the equity impact of index changes carries over to international indices (i.e., that the global demand for stocks slopes down). The significant intercept $\alpha_{1}$ identifies common factors affecting equity markets around the world over the event window, as well as an appreciation of most sample currencies against the U.S. dollar for U.S. dollar returns.

\subsection{Currency market}

Having established that the index redefinition has an impact on individual stocks, we investigate whether its effect spreads to currencies. First, we 


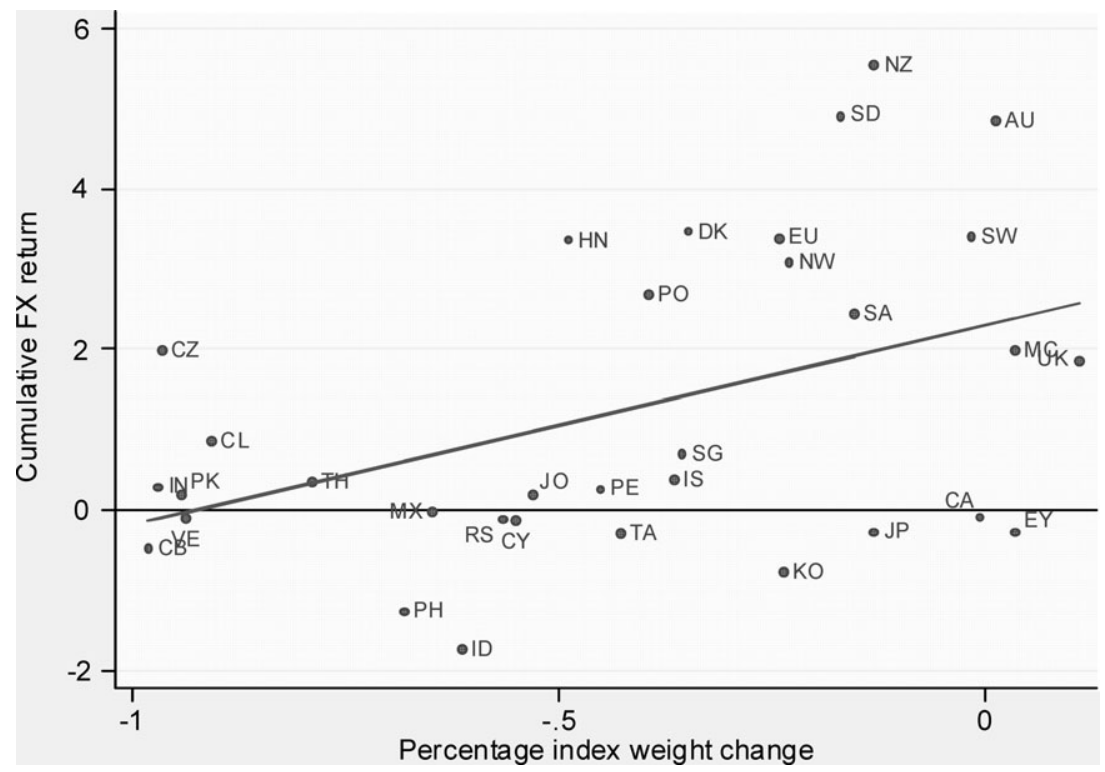

Figure 3

Exchange rate returns (denominated in U.S. dollar per local currency and expressed in percentage points) over a six-day window $\left(\Delta e_{i}^{6}\right)$ are plotted against the index weight changes $\left(\Delta w_{i}\right)$

The solid curve displays the fitted values from an OLS regression of exchange rate returns on index changes. The regression yields $\Delta e_{i}^{6}=2.30+2.49 * \Delta w_{i}$, where the $t$-statistics on $\Delta w_{i}$ equal 2.99 , the number of observations is 33 , and the $R^{2}$ equals $17 \%$. The sample countries consists of the fifty countries in MSCI ACWI index from which were excluded the United States, the eleven Euro zone countries that were aggregated into one, three countries with pegged currencies (China, Hong Kong, and Malaysia), and three countries that experienced a major currency crisis around the time of our analysis (Argentina, Brazil, and Turkey). See Figure 2 for country labels.

represent the exchange rate behavior around the announcement date visually. Figure 3 plots exchange rate returns over a six-day window against a country's percentage weight change. The upward sloping regression line indicates that a weight increase leads to a currency appreciation. The economic magnitude of the effect is sizable. The fitted line has a slope of 2.49 , which implies that a $10 \%$ weight increase of a currency is associated with a $0.249 \%$ appreciation. Approximately US\$300 billion is directly benchmarked to the MSCI index. The average currency has a weight of $2.2 \%$ in the index. A $10 \%$ weight increase therefore translates into a capital flow of US\$0.66 billion $(0.022 \times 0.1 \times 300$ bn). An (uninformative) capital flow of US\$1 billion therefore amounts to an average appreciation of $0.38 \%(0.249 \% / 0.66)$. As a comparison, Evans and Lyons (2002a) estimate that a US\$1 billion (informative) FX orderflow moves the US\$/DM exchange rate by $0.5 \%$.

We can also characterize the elasticity of arbitrageurs' demand for currencies as $40.16(1 / 2.49 \%)$. This elasticity is substantially larger than that estimated for stocks by Kaul, Mehrotra, and Morck (2000) and Wurgler and Zhuravskaya 


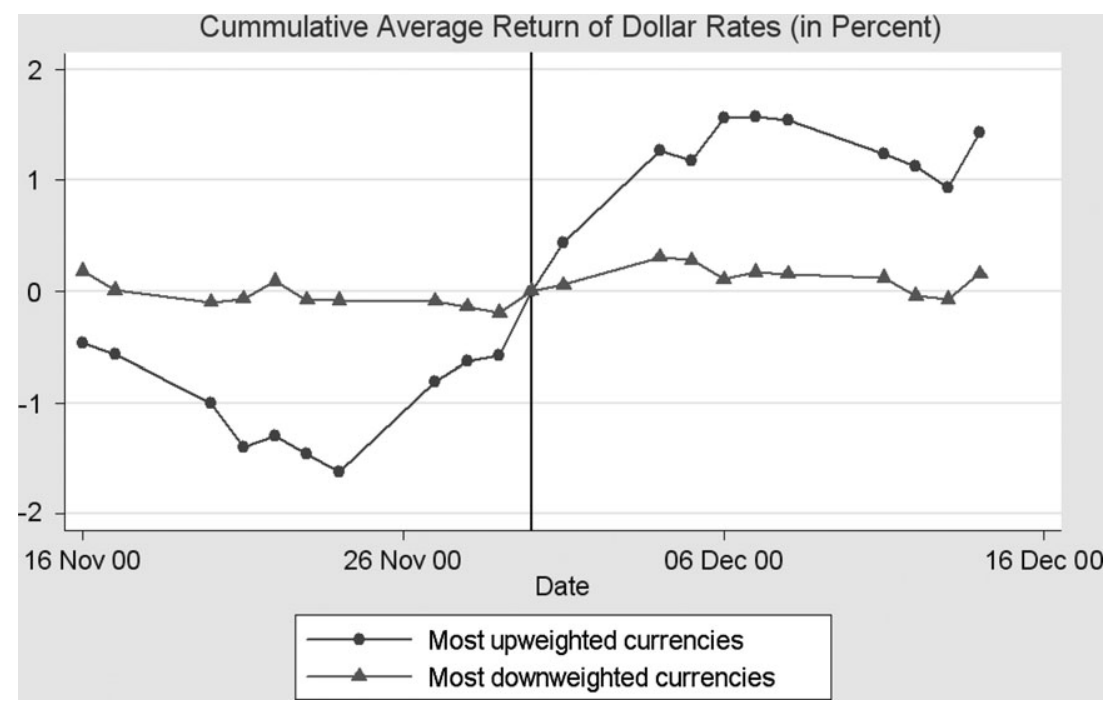

Figure 4

The average cumulative exchange rate returns (denominated in U.S. dollar per local currency and expressed in percentage points) are plotted for the sixteen most upweighted and seventeen most downweighted currencies around the announcement of the MSCI index redefinition (December 1, 2000)

For the event day, the cumulative returns are normalized to be zero. The sample countries consist of the fifty countries in the MSCI Global Equity Index (ACWI) from which were excluded the United States, the eleven Euro zone countries that were aggregated into one, three countries with pegged currencies (China, Hong Kong, and Malaysia), and three countries that experienced a major currency crisis around the time of our analysis (Argentina, Brazil, and Turkey).

(2002). ${ }^{21}$ It reflects arbitrageurs' greater willingness to flatten the aggregate demand curve for currencies. This is expected given the higher liquidity of FX market.

The sample of thirty-three countries is then split into two subsamples containing the sixteen (most) upweighted and the seventeen (most) downweighted countries. Figures 4 and 5 show an equally weighted index representing the average cumulative exchange rate effect for each subsample. Figure 4 uses the U.S. dollar as the reference currency while Figure 5 uses a basket of currencies, weighted according to their capitalization in the MSCI Global Equity Index in order to neutralize any U.S. dollar effect (the U.S. dollar weakened against the basket over the period). Both figures show that upweighted countries experienced an exchange rate appreciation compared to downweighted countries. The gap across the two groups grows almost continuously over the eight trading days from November 27 to December 6, 2000. Information leakages prior to December 1, 2000, as well as a slow information diffusion thereafter may explain the gradual nature of the effect. The figures also give insights into its

21 Kaul, Mehrora and Morck (2000) report an elasticity of 10.5 based on the revision of the Toronto Stock Exchange 300 index. Wurgler and Zhuravskaya (2002) estimate an elasticity of 8.24 based on additions to the S\&P 500 index. 


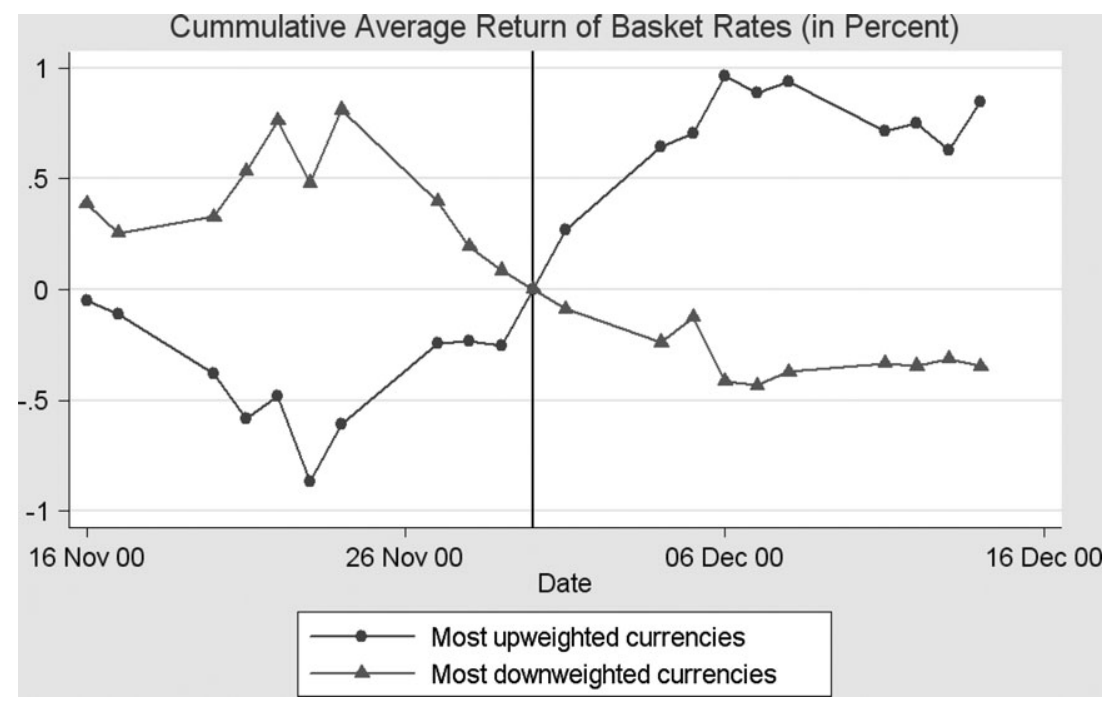

Figure 5

The average cumulative exchange rate returns (expressed relative to a basket of currencies and in percentage points) are plotted for the sixteen most upweighted and seventeen most downweighted currencies around the announcement of the MSCI index redefinition (December 1, 2000)

For the event day, the cumulative returns are normalized to be zero. The sample countries consist of the fifty countries in the MSCI Global Equity Index (ACWI) from which were excluded the United States, the eleven Euro zone countries that were aggregated into one, three countries with pegged currencies (China, Hong Kong, and Malaysia), and three countries that experienced a major currency crisis around the time of our analysis (Argentina, Brazil, and Turkey).

economic significance. Over the eight trading days, the exchange rate gap exceeds $2 \%$. The average percentage weight change in the sample of upweighted countries is $-15 \%$, while the average percentage weight change in the subsample of downweighted countries is $-70 \%$. We conclude that the economic significance of the exchange rate effect is considerable.

We discuss next the statistical significance of the exchange rate effect. Table 3 presents the results of the Fisher test on the two subsamples. For each currency, we compute cumulative changes over a six-day and twelve-day window around the event. The Fisher test rejects the null hypothesis for both window sizes at a $1 \%$ level. We conclude that there is a statistically significant relationship between weight and exchange rate changes, as postulated by Hypothesis $\mathrm{H} 2$.

To explore exchange rate correlation clustering in the dimension of the weight change, we calculate daily currency returns over a 4-year period prior to July 1 , 2000. Exchange rate behavior during this period should not be affected by the changes to the index announced much later. We form all $528(0.5 \times 33 \times 32)$ currency pairs and calculate the correlations for (i) pairs of only upweighted currencies, (ii) pairs of only downweighted currencies, and (iii) pairs of one up- and one downweighted currency. The correlation statistics are reported in Table 4. The group of upweighted currencies clearly has the highest mutual correlation, with an average of $20.8 \%$ relative to an overall correlation of $10.4 \%$ 
Table 3

Nonparametric test for independence of MSCI index reweighting and exchange rate change

Window size

6 Days

Two-sided Fisher test

$p$-value

0.005

0.000

One-sided Fisher test

$p$-value

0.004

Number of obs.

The sample currencies are split into the sixteen most upweighted and the seventeen most downweighted currencies and alternatively into the sixteen appreciating and the seventeen most depreciating currencies. The Fisher test evaluates the likelihood of observed association under the null hypothesis that there is no relationship between the two sorting criteria. The currency appreciations are measured as the cumulative return (in U.S. dollars per local currency) over a six- and twelve-day window around the announcement day of the index reweighting (December 1, 2000). The sample countries consist of the fifty countries in the MSCI Global Equity Index (ACWI) index from which were excluded the United States, the eleven Euro zone countries that were aggregated into one, three countries with pegged currencies (China, Hong Kong, and Malaysia), and three countries that experienced a major currency crisis around the time of our analysis (Argentina, Brazil, and Turkey).

Table 4

Correlation structure of currency pairs

\begin{tabular}{|c|c|c|c|c|c|c|c|c|}
\hline \multicolumn{3}{|c|}{ Groups of currency pairs } & \multirow{2}{*}{$\begin{array}{c}\text { Obs. } \\
120\end{array}$} & \multirow{2}{*}{$\begin{array}{l}\text { Mean } \\
0.208\end{array}$} & \multirow{2}{*}{$\begin{array}{c}\text { Median } \\
0.132\end{array}$} & \multirow{2}{*}{$\begin{array}{l}\text { S.D. } \\
0.257\end{array}$} & \multirow{2}{*}{$\begin{array}{c}\text { Min } \\
-0.093\end{array}$} & \multirow{2}{*}{$\begin{array}{l}\text { Max } \\
0.985\end{array}$} \\
\hline (1) & $\operatorname{Corr}\left(\Delta e_{i_{1}}^{u p}, \Delta e_{i_{2}}^{u p}\right)$ & & & & & & & \\
\hline (2) & $\operatorname{Corr}\left(\Delta e_{i_{1}}^{d w}, \Delta e_{i_{2}}^{d w}\right)$ & & 136 & 0.061 & 0.040 & 0.108 & -0.071 & 0.608 \\
\hline (3) & $\operatorname{Corr}\left(\Delta e_{i_{1}}^{u p}, \Delta e_{i_{2}}^{d^{2} w}\right)$ & & 272 & 0.081 & 0.033 & 0.166 & -0.281 & 0.862 \\
\hline All & $\operatorname{Corr}\left(\Delta e_{i_{1}}, \Delta e_{i_{2}}\right)$ & & 528 & 0.104 & 0.046 & 0.188 & -0.280 & 0.985 \\
\hline \multicolumn{9}{|l|}{ Fisher test } \\
\hline Two-sided test & ( $p$-value) & 0.004 & & & & & & \\
\hline One-sided test & ( $p$-value) & 0.002 & & & & & & \\
\hline
\end{tabular}

We form all 528 currency pairs and calculate the correlation of $(\log )$ daily exchange rate changes for the fouryear period from July 1, 1996, to July 1, 2000. We group currencies into the sixteen most upweighted and seventeen most downweighted ones. Reported are summary statistics for the correlation of (i) currency pairs for which both currencies are upweighted, (ii) currency pairs for which both currencies are downweighted, and (iii) currency pairs for which one currency is upweighted and the other is downweighted. The Fisher test evaluates the likelihood of the observed association (under the null hypothesis of no relationship) between the criterion $(\mathrm{C} 1)$ of having an above median correlation for any currency pair and the criterion (C2) that both currencies in this pair are from the same group of either only up- or only downweighted currencies. The sample countries consist of the fifty countries in the MSCI Global Equity Index (ACWI) from which were excluded the United States, the eleven Euro zone countries that were aggregated into one, three countries with pegged currencies (China, Hong Kong, and Malaysia), and three countries that experienced a major currency crisis around the time of our analysis (Argentina, Brazil, and Turkey).

for all currency pairs. Exchange rate correlations are clustered in the dimension of weight changes. In particular, the median correlation of currency pairs within the same weight-change group is higher than for pairs across groups. The Fisher test in Table 4 confirms the association of weight-change group and correlation clustering at a $1 \%$ significance level.

In Tables 5 and 6 (column 1), we report the estimation results for the regressions using a general covariance structure across currencies and time that accounts for correlation clustering. In Table 5, based on weekly observations, the slope coefficient $\alpha_{2}$ in column 1 has a positive and statistically significant sign. It implies a return difference between the average upweighted and 
Table 5

Regressions for weekly exchange rate returns

\begin{tabular}{lcccc} 
& $(1)$ & $(2)$ & $(3)$ & $(4)$ \\
Scaling factor $\left(S F_{i}\right)$ & $\frac{1}{2}\left(w_{i}^{n}+w_{i}^{o}\right)$ & $\frac{1}{2}\left(w_{i}^{n}+w_{i}^{o}\right)$ & $\operatorname{Vol}_{i}^{F X}$ & $\operatorname{Vol}_{i}^{S P}$ \\
\hline$D_{t}$ & $1.345^{* * *}$ & $1.455^{* * *}$ & $1.500^{* * *}$ & $1.500^{* * *}$ \\
$\Delta \bar{w}_{i} \times D_{t}$ & $(0.446)$ & $(0.508)$ & $(0.512)$ & $(0.512)$ \\
& $2.159^{* * *}$ & $2.567^{* * *}$ & $1.727^{* * *}$ & $0.957^{* * *}$ \\
$R^{2}$ (for event week) & $(0.658)$ & $(0.802)$ & $(0.523)$ & $(0.286)$ \\
Currency obs. & 0.380 & 0.404 & 0.375 & 0.384 \\
Time obs. & 33 & 27 & 27 & 27 \\
& 174 & 174 & 174 & 174
\end{tabular}

We perform OLS regressions of the (log) weekly exchange rate change $\Delta e_{i t}$ (denominated in U.S. dollar per local currency and expressed in percentage points) on the scaled country weight changes $\Delta \bar{w}_{i}$ defined as the (demeaned) ratio of the weight change $w_{i}^{n}-w_{i}^{o}$ of each currency $i$ and scaling factors $\left(S F_{i}\right)$. The respective scaled weight change is interacted with a time dummy $D_{t}$ marking the event week around the announcement event (December 1, 2000), resulting in the following specification:

$$
\Delta e_{i t}=\alpha_{0}+\alpha_{1} D_{t}+\alpha_{2}\left(\Delta \bar{w}_{i} \times D_{t}\right)+\mu_{i t} .
$$

As scaling factors for weight changes we use: the average of a country's new and old new weights, $\frac{1}{2}\left(w_{i}^{n}+w_{i}^{o}\right)$, in Columns 1 and 2; its total FX currency market volume, $\operatorname{Vol}_{i}^{F X}$, in Column 3; and its total FX spot market volume, $\operatorname{Vol}_{i}^{S P}$, in Column (4). In addition to spot trading volume, total FX volume includes outright forward contracts and swap contracts. The estimation uses four years of weekly data exchange rate data from July 1 , 1996, to July 1, 2000. The sample countries consist of the fifty countries in the MSCI Global Equity Index (ACWI) from which are excluded the United States, the eleven Euro zone countries that are aggregated into one, three countries with pegged currencies (China, Hong Kong, and Malaysia), and three countries that experienced a major currency crisis around the time of our analysis (Argentina, Brazil, and Turkey). FX volume data obtained from the BIS survey of April 2001 is available only for a reduced set of twenty-seven currencies. Standard errors for correlated panels accounting for a general covariance structure across of all currencies and time are reported in parentheses. We indicate by ${ }^{*},{ }^{* *}$, and ${ }^{* * *}$ significance at the $5 \%, 3 \%$, and $1 \%$ level, respectively. The constant term is not reported.

downweighted currencies of $1.19 \%(2.159 \times 0.55)$ over a week. The positive coefficient $\alpha_{1}$ indicates that the event week was marked by an appreciation of most sample currencies against the U.S. dollar. The explanatory power over the event week is remarkably strong. The $R^{2}$ is $38 \%$, compared to $0.8 \%$ over the entire sample period.

Table 6 presents similar results using daily returns. The number of time-series observations increases from 174 weekly returns in Table 5 to 980 daily returns in Table 6. A small number of return outliers during the Asian and Russian currency crisis were discarded. ${ }^{22}$ Column 1 in panel A (six-day window) and panel B (twelve-day window) displays estimates of the coefficient $\alpha_{2}$ that are positive and statistically significant at the $1 \%$ level. The coefficient implies an average return difference of $1.36 \%(0.413 \times 0.55 \times 6)$ between upweighted and downweighted currencies over six trading days. Again, the explanatory power over the event period is strong (the $R^{2}$ is approximately $20 \%$ and $13 \%$ in the six- and twelve-day windows, compared to $0.2 \%$ over the entire sample period).

Finally, we exploit the daily orderflow data in the Euro/U.S. dollar market. Column 2 in Table 6 shows that the orderflow $\overline{O F}_{t}$ itself does not explain

22 We discard a daily return observation if the exchange rate moved by more than $5 \%$ over one day. 
Table 6

Regression for daily exchange rate returns

Panel A: Six-day event window

\begin{tabular}{lcccccc}
\hline & $(1)$ & $(2)$ & $(3)$ & $(4)$ & $(5)$ & $(6)$ \\
Scaling factor $\left(S F_{i}\right)$ & $\frac{1}{2}\left(w_{i}^{n}+w_{i}^{o}\right)$ & $\frac{1}{2}\left(w_{i}^{n}+w_{i}^{o}\right)$ & $\operatorname{Vol}_{i}^{F X}$ & $\operatorname{Vol}_{i}^{F X}$ & $\operatorname{Vol}_{i}^{S P}$ & $\operatorname{Vol}_{i}^{S P}$ \\
\hline$D_{t}$ & $0.230^{* * *}$ & $0.230^{* * *}$ & $0.267^{* * *}$ & $0.267^{* * *}$ & $0.267^{* * *}$ & $0.267^{* * *}$ \\
$\Delta \bar{w}_{i} \times D_{t}$ & $(0.081)$ & $(0.081)$ & $(0.094)$ & $(0.094)$ & $(0.094)$ & $(0.094)$ \\
& $0.413^{* * *}$ & $0.413^{* * *}$ & $0.286^{* * *}$ & $0.286^{* * *}$ & $0.155^{* * *}$ & $0.155^{* * *}$ \\
$O F_{t} \times D_{t}$ & $(0.130)$ & $(0.130)$ & $(0.105)$ & $(0.105)$ & $(0.057)$ & $(0.057)$ \\
& & -0.019 & & 0.075 & & 0.075 \\
$\Delta \bar{w}_{i} \times \overline{O F}_{t} \times D_{t}$ & & $(0.078)$ & & $(0.088)$ & & $(0.088)$ \\
& & 0.191 & & 0.159 & & 0.089 \\
$R^{2}($ event period) & 0.183 & 0.206 & 0.178 & 0.200 & 0.180 & 0.204 \\
Currency obs. & 33 & 33 & 27 & 27 & 27 & 27 \\
Time obs. & 980 & 980 & 980 & 980 & 980 & 980
\end{tabular}

Panel B: Twelve-day event window

\begin{tabular}{|c|c|c|c|c|c|c|}
\hline Scaling factor $\left(S F_{i}\right)$ & $\begin{array}{c}(1) \\
\frac{1}{2}\left(w_{i}^{n}+w_{i}^{o}\right)\end{array}$ & $\begin{array}{c}(2) \\
\frac{1}{2}\left(w_{i}^{n}+w_{i}^{o}\right)\end{array}$ & $\begin{array}{c}(3) \\
\operatorname{Vol}_{i}^{F X}\end{array}$ & $\begin{array}{c}(4) \\
\operatorname{Vol}_{i}^{F X}\end{array}$ & $\begin{array}{c}(5) \\
\operatorname{Vol}_{i}^{S P}\end{array}$ & $\begin{array}{c}(6) \\
V o l_{i}^{S P}\end{array}$ \\
\hline$D_{t}$ & $\begin{array}{l}0.143^{* *} \\
(0.057)\end{array}$ & $\begin{array}{l}0.143^{* *} \\
(0.057)\end{array}$ & $\begin{array}{l}0.166^{* *} \\
(0.067)\end{array}$ & $\begin{array}{l}0.166^{* *} \\
(0.067)\end{array}$ & $\begin{array}{l}0.166^{* *} \\
(0.067)\end{array}$ & $\begin{array}{l}0.166^{* *} \\
(0.067)\end{array}$ \\
\hline$\frac{w_{i}^{n}-w_{i}^{o}}{S F_{i}} \times D_{t}$ & $\begin{array}{l}0.300^{* * *} \\
(0.093)\end{array}$ & $\begin{array}{l}0.300^{* * *} \\
(0.092)\end{array}$ & $\begin{array}{l}0.199^{* * *} \\
(0.074)\end{array}$ & $\begin{array}{l}0.199^{* * *} \\
(0.074)\end{array}$ & $\begin{array}{l}0.109^{* * *} \\
(0.040)\end{array}$ & $\begin{array}{l}0.109^{* * *} \\
(0.040)\end{array}$ \\
\hline$\overline{O F}_{t} \times D_{t}$ & & $\begin{array}{c}-0.007 \\
(0.056)\end{array}$ & & $\begin{array}{c}0.110 \\
(0.063)\end{array}$ & & $\begin{array}{c}0.110 \\
(0.063)\end{array}$ \\
\hline$\frac{w_{i}^{n}-w_{i}^{o}}{S F_{i}} \times \overline{O F}_{t} \times D_{t}$ & & $\begin{array}{l}0.229^{* * *} \\
(0.088)\end{array}$ & & $\begin{array}{l}0.184^{* * *} \\
(0.071)\end{array}$ & & $\begin{array}{l}0.102^{* * *} \\
(0.038)\end{array}$ \\
\hline $\begin{array}{l}R^{2} \text { (event period) } \\
\text { Currency obs. } \\
\text { Time obs. }\end{array}$ & $\begin{array}{l}0.085 \\
33 \\
986\end{array}$ & $\begin{array}{c}0.129 \\
33 \\
986\end{array}$ & $\begin{array}{l}0.083 \\
27 \\
986\end{array}$ & $\begin{array}{c}0.083 \\
27 \\
986\end{array}$ & $\begin{array}{l}0.083 \\
27 \\
986\end{array}$ & $\begin{array}{c}0.134 \\
27 \\
986\end{array}$ \\
\hline
\end{tabular}

We perform OLS regressions of the (log) daily exchange rate change $\Delta e_{i t}$ (denominated in U.S. dollar per local currency and expressed in percentage points) on the scaled weight change $\Delta \bar{w}_{i}$ defined as the (demeaned) ratio of the weight change $w_{i}^{n}-w_{i}^{o}$ of each currency $i$ and scaling factors $\left(S F_{i}\right)$, the (demeaned) orderflow in the Euro/U.S. dollar market $\overline{O F}_{t}$, and the interaction term $\Delta \bar{w}_{i} \times \overline{O F}_{t}$. Each term is interacted with a dummy variable $D_{t}$, which marks alternatively an event window of six trading days (panel A) or twelve trading days (panel B) around the announcement of the index redefinition (December 1, 2000). Formally, the regression specification is given by

$$
\Delta e_{i t}=\alpha_{0}+\alpha_{1} D_{t}+\alpha_{2}\left(\Delta \bar{w}_{i} \times D_{t}\right)+\alpha_{3}\left(\overline{O F}_{t} \times D_{t}\right)+\alpha_{4}\left(\Delta \bar{w}_{i} \times \overline{O F}_{t} \times D_{t}\right)+\mu_{i t} .
$$

As scaling factors for weight changes we use: the average of a country's new and old new weights $\frac{1}{2}\left(w_{i}^{n}+w_{i}^{o}\right)$, in Columns 1 and 2; its total FX currency market volume, $\operatorname{Vol}_{i}^{F X}$, in Columns 3 and 4; and its total FX spot market volume, $\operatorname{Vol}_{i}^{S P}$, in Columns 5 and 6 . In addition to spot trading volume, total FX volume includes outright forward contracts and swap contracts. The estimation uses 4 years of daily data exchange rate data from July 1, 1996, to July 1, 2000. The sample countries consist of the fifty countries in the MSCI Global Equity Index (ACWI) from which we excluded the United States, the eleven Euro zone countries that were aggregated into one, three countries with pegged currencies (China, Hong Kong, and Malaysia), and three countries that experienced a major currency crisis around the time of our analysis (Argentina, Brazil, and Turkey). FX volume data obtained from the BIS survey of April 2001 is available only for a reduced set of twenty-seven currencies. Standard errors for correlated panels accounting for a general covariance structure across all currencies and time are reported in parentheses. We indicate by ${ }^{*},{ }^{* *}$, and ${ }^{* * *}$ significance at the $5 \%, 3 \%$, and $1 \%$ level, respectively. The constant term is not reported. 
the intertemporal pattern of exchange rate changes around the announcement. However, the interaction term between weight changes and orderflow during the event window days, namely $\Delta \bar{w}_{i} \times \overline{O F}_{t} \times D_{t}$, produces a statistically significant positive coefficient in panel B. Intuitively, orderflow in the U.S. dollar/ Euro market proxies for the intertemporal intensity of currency speculation in favor of the U.S. dollar. Over the event window, orderflow should pick up currency speculation related to the MSCI Global Equity Index weight change. Interacted with the weight change, it proxies for "speculation intensity" in each individual currency. The positive sign on the coefficient $\alpha_{4}$ provides additional support in favor of a downward sloping demand for currencies. The coefficient $\alpha_{2}$ captures the time average of the weight change impact and remains positive, significant, and of similar magnitude as in column 1.

\subsection{Robustness checks}

In this section, we check whether the results obtain under alternative normalizations of the weight change. We relied so far on the change in countries' index representation to predict their currency impact. We used relative weight change since one would expect this impact to depend on the size of the FX markets-currencies in which the daily trading volume is smaller should be more sensitive to the index redefinition. Specifically, we divided a measure of the absolute (U.S. dollar) flow into country $i$ 's currency, $w_{i}^{n}-w_{i}^{o}$, by the value (in U.S. dollars) of country $i$ 's equity in the index, $\left(w_{i}^{n}+w_{i}^{o}\right) / 2$. We assumed that the latter is positively related to the size of the market for currency $i$.

To check the robustness of our results, we scale instead the absolute weight change with direct estimates of the size of the currency market. Obtaining data on daily currency trading volume is not an easy task. Therefore, we rely on three yearly surveys published by the Bank for International Settlement (BIS). ${ }^{23}$ The survey closest to the MSCI redefinition was undertaken in April 2001 and the average daily FX volumes are published by currency and trading instrument. We derive two proxies for trading volume: Spot FX Volume and Total FX Volume. The latter measure includes outright forward contracts and swap contracts. Figures 6 and 7 show that both proxies are closely related to our previous scaling variable. Figure 6 (respectively Figure 7) plots the log Spot FX Volume (respectively Total FX volume) against the log average of the old and new weights, $\left(w_{i}^{n}+w_{i}^{o}\right) / 2$. A formal test based on a linear regression indicates that the log of the MSCI weights explains $85 \%$ (respectively $80 \%$ ) of the variation in the log Spot FX Volume (respectively Total FX volume).

We then reestimate both the daily and weekly currency regressions using these new proxies for trading volume. The results are reported in Table 5, columns 3 and 4, and in Table 6, columns 3-6. They confirm the previous conclusions: The index rebalancing has a strong impact on currencies whether

23 The BIS survey does not report FX trading volume data for six countries, namely Egypt, Jordan, Sri Lanka, Morocco, Pakistan, and Venezuela. These countries were dropped from the subsequent analysis. 


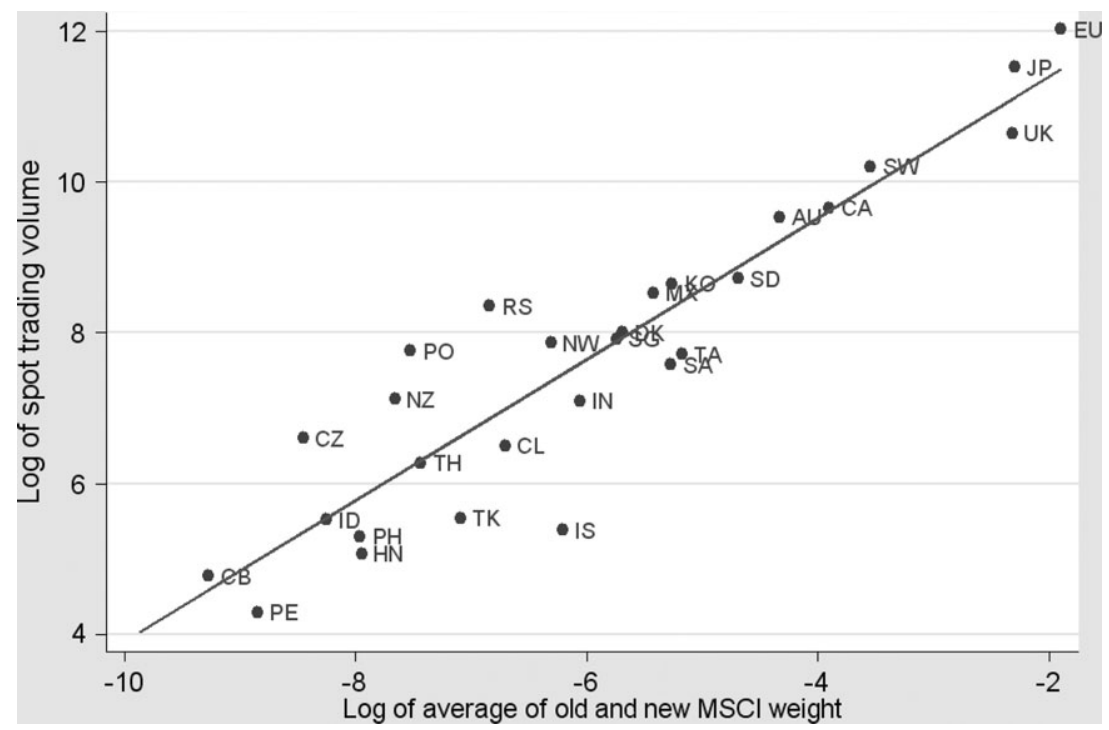

Figure 6

The spot FX trading volume as a function of the average of the old and new MSCI index weights

The figure plots the log spot FX volume against the log average of the old and new weights, $\left(w_{i}^{n}+w_{i}^{o}\right) / 2$. FX volume data are obtained from the BIS April 2001 Survey. The sample countries consist of the fifty countries in the MSCI Global Equity Index (ACWI), from which were excluded the United States, the eleven Euro zone countries that were aggregated into one, three countries with pegged currencies (China, Hong Kong, and Malaysia), three countries that experienced a major currency crisis around the time of our analysis (Argentina, Brazil, and Turkey), and six countries not surveyed by the BIS (Egypt, Jordan, Sri Lanka, Morocco, Pakistan, and Venezuela).

we use the six-day or the twelve-day window. For example, in the case of a six-day window (Table 6, panel A), a one standard deviation increase in a country's weight changes leads to a $0.71 \%(0.155 \times 0.76 \times 6)$ appreciation in its currency if the scaling is based on Spot FX Volume and to a $0.67 \%$ $(0.286 \times 0.39 \times 6)$ appreciation if the scaling is based on Total FX Volume.

In summary, all three statistical procedures (Fisher test, regressions on weight changes, and regressions on weight changes interacted with the Euro/U.S. dollar orderflow) and the various definitions of the weight changes show a positive and statistically significant relationship between weight increases and currency appreciations. The exact magnitude of the effect is sensitive to the window size, estimation procedure, and the weight definition, and cannot be determined with much accuracy. But the qualitative results are robust across window sizes, sampling frequencies, and alternative time spans for the exchange rate data. ${ }^{24}$ The results also obtain when we do not exclude the three countries that experienced a currency crisis during our data period (Turkey, Argentina, and Brazil) or the three countries with a pegged currency (China, Malaysia, and Hong Kong). In addition, weight changes interacted with orderflow account for the panel

24 We confirmed the results using exchange rate data spanning two or three years instead of four years. 


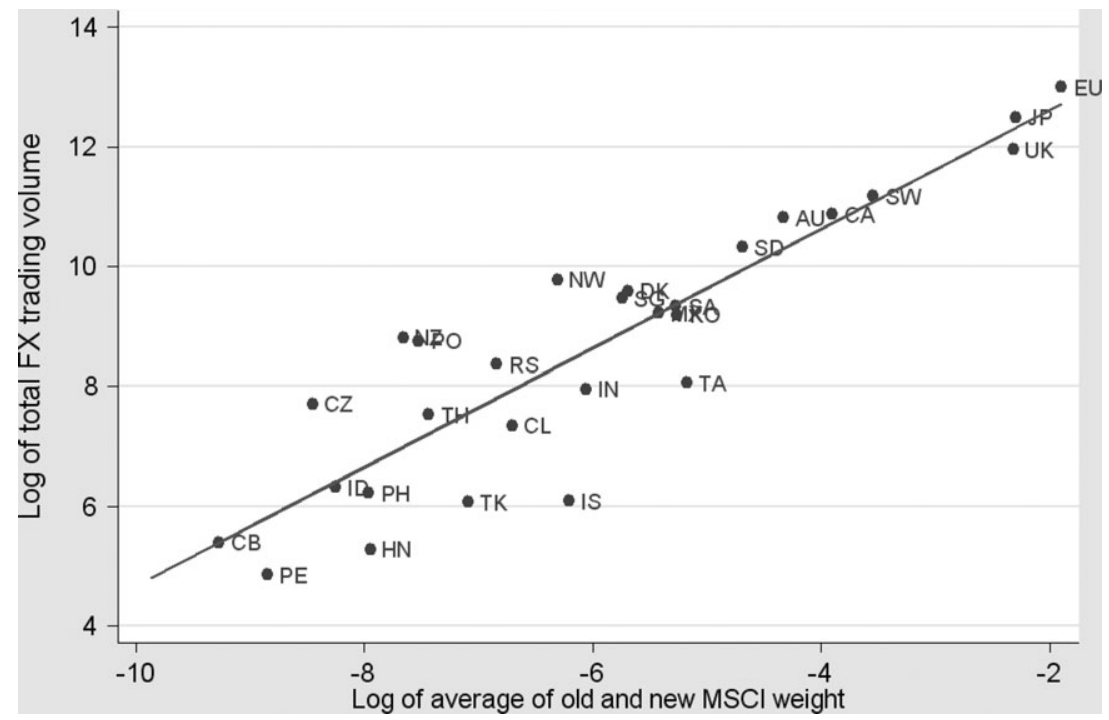

Figure 7

The spot FX trading volume as a function of the average of the old and new MSCI index weights

The figure plots the log total FX volume against the log average of the old and new weights, $\left(w_{i}^{n}+w_{i}^{o}\right) / 2$. In addition to spot trading volume, Total FX Volume includes outright forward contracts and swap contracts and is obtained from the BIS April 2001 Survey. The sample countries consist of the fifty countries in the MSCI Global Equity Index (ACWI) from which were excluded the United States, the eleven Euro zone countries that were aggregated into one, three countries with pegged currencies (China, Hong Kong, and Malaysia), three countries that experienced a major currency crisis around the time of our analysis (Argentina, Brazil, and Turkey), and six countries not surveyed by the BIS (Egypt, Jordan, Sri Lanka, Morocco, Pakistan, and Venezuela).

structure of currency returns around the announcement event. This is consistent with the idea that orderflow in the Euro/U.S. dollar market proxies for speculative intensity in all currencies. Overall, the evidence strongly supports the notions that shocks originating in the equity market spill over to the currency market, and that currencies are imperfect substitutes for one another.

\subsection{Implementation effects}

We have focused so far on the market's reaction to the announcement of the MSCI Global Equity Index redefinition. We examine next the market's reaction to its implementation. As described above, the redefinition took place in two steps. On November 31, 2001, half of the changes were implemented for the existing index constituents and all the new constituents were added at half of their final weight. The rest of the changes occurred on May 31, 2002.

Previous studies that distinguish between a price impact occurring at the announcement of an index change from one occurring at its implementation find evidence of a "reversal" on the implementation day. Such a pattern has been observed, for example, in the case of changes to the S\&P 500 index occurring after 1990, when S\&P started announcing changes to its index. Beneish and Whaley (1996) and Lynch and Mendenhall (1997) report that added stocks 
Table 7

Stock and exchange returns around the first implementation of the MSCI index redefinition (November 30, 2001)

Panel A: Individual stock returns in local currency

$\Delta r_{i j}=\alpha_{0}+\alpha_{1} \Delta w_{i j}+\mu_{i j}$

\begin{tabular}{|c|c|c|c|c|c|c|}
\hline \multirow[b]{2}{*}{ Window size } & \multicolumn{2}{|c|}{$\begin{array}{l}\text { Raw returns } \\
\text { OLS }\end{array}$} & \multicolumn{2}{|c|}{$\begin{array}{l}\text { Raw returns } \\
\text { OLS clustered }\end{array}$} & \multicolumn{2}{|c|}{$\begin{array}{l}\text { Abnormal returns } \\
\text { OLS clustered }\end{array}$} \\
\hline & $\begin{array}{l}(1) \\
6 \text { Days }\end{array}$ & $\begin{array}{c}(2) \\
12 \text { Days }\end{array}$ & $\begin{array}{c}\text { (3) } \\
6 \text { Days }\end{array}$ & $\begin{array}{c}(4) \\
12 \text { Days }\end{array}$ & $\begin{array}{l}\text { (5) } \\
6 \text { Days }\end{array}$ & $\begin{array}{c}(6) \\
12 \text { Days }\end{array}$ \\
\hline Constant & $\begin{array}{l}1.043^{* * *} \\
(0.143)\end{array}$ & $\begin{array}{l}2.240^{* * * *} \\
(0.212)\end{array}$ & $\begin{array}{c}1.043 \\
(0.740)\end{array}$ & $\begin{array}{l}2.240^{* * * *} \\
(0.939)\end{array}$ & $\begin{array}{r}-0.079 \\
(0.239)\end{array}$ & $\begin{array}{l}0.765^{* *} \\
(0.329)\end{array}$ \\
\hline$\Delta w_{i j}$ & $\begin{array}{c}-0.453^{\text {**** }} \\
(0.118)\end{array}$ & $\begin{array}{c}-0.864^{* * *} \\
(0.175)\end{array}$ & $\begin{array}{c}-0.453 \\
(0.311)\end{array}$ & $\begin{array}{c}-0.864^{* * *} \\
(0.301)\end{array}$ & $\begin{array}{c}-0.625^{\text {**** }} \\
(0.185)\end{array}$ & $\begin{array}{c}-0.898^{\text {**** }} \\
(0.206)\end{array}$ \\
\hline $\begin{array}{l}\text { Obs. } \\
R^{2}\end{array}$ & $\begin{array}{l}2432 \\
0.0057\end{array}$ & $\begin{array}{l}2432 \\
0.0094\end{array}$ & $\begin{array}{l}2432 \\
0.0057\end{array}$ & $\begin{array}{l}2432 \\
0.0094\end{array}$ & $\begin{array}{l}2362 \\
0.0115\end{array}$ & $\begin{array}{l}2362 \\
0.0102\end{array}$ \\
\hline
\end{tabular}

Panel B: Exchange rate returns

\begin{tabular}{|c|c|c|c|c|c|}
\hline \multicolumn{3}{|c|}{ Nonparametric Fisher test } & \multicolumn{3}{|c|}{$\begin{array}{l}\text { Weekly currency return regressions } \\
\Delta e_{i t}=\alpha_{0}+\alpha_{1} D_{t}+\alpha_{2}\left(\Delta \bar{w}_{i} \times D_{t}\right)+\mu_{i t}\end{array}$} \\
\hline Window size & 6 Days & 12 Day & Window size & 6 Days & 12 Days \\
\hline $\begin{array}{l}\text { Two-sided } \\
p \text {-value } \\
\text { One-sided } \\
p \text {-value }\end{array}$ & 0.169 & $\begin{array}{c}D_{t} \\
1.000\end{array}$ & $\begin{array}{c}0.014 \\
\Delta w_{i} \times D_{t}\end{array}$ & $\begin{array}{c}0.042 \\
(0.081) \\
-0.070 \\
(0.100)\end{array}$ & $\begin{array}{c}(0.057) \\
-0.050 \\
(0.071)\end{array}$ \\
\hline Obs. & 33 & 33 & $\begin{array}{l}\text { Currency obs. } \\
\text { Time obs. }\end{array}$ & $\begin{array}{c}33 \\
980\end{array}$ & $\begin{array}{c}33 \\
986\end{array}$ \\
\hline
\end{tabular}

We analyze individual stock returns (panel A) and exchange returns (panel B) around the first implementation of the MSCI index redefinition. The index adjusted 50\% toward the new index on November 30, 2001, and the remaining adjustment occurred on May 31, 2002. See Table 2 for details on the individual stock return regressions. See Table 3 for details on the nonparametric Fisher test carried out on exchange rates, and Table 6 for details on the regressions on daily currency returns. The currency return regressions in Panel B use the scaled (and demeaned) weight change $\Delta \bar{w}_{i}$ with the scaling factor $S F_{i}=\frac{1}{2}\left(w_{i}^{n}+w_{i}^{o}\right)$ interacted with a time dummy $D_{t}$ marking alternatively a 6- or 12-trading-day event window around November 30, 2001. Standard errors for correlated panels accounting for a general covariance structure across all currencies are reported in parentheses. We indicate by ${ }^{*},{ }^{* *}$, and ${ }^{* * *}$ significance at the $5 \%, 3 \%$, and $1 \%$ level, respectively.

earn positive abnormal returns upon announcement but negative abnormal returns upon implementation, thereby partially offsetting the initial gains. The common interpretation is that arbitrageurs trading on the announcement date overestimate the demand by index funds adjusting their portfolios on the implementation date.

Our results are consistent with these studies. Table 7 displays the equity and currency responses on the first implementation date (November 31, 2001). Panel A reports results based on U.S. dollar stock returns. Results for local currency stock returns are similar and omitted for brevity. In contrast to the announcement event, the estimated coefficient on the weight change is negative in most specifications, indicating that upweighted stocks earned negative returns upon implementation. The results for currencies also differ from those of 
the announcement event. Panel B presents nonparametric Fisher tests and OLS estimations similar to those carried out at the announcement, with a general covariance structure that accounts for correlation clustering. The Fisher test reveals no statistical difference in exchange rates across up- and downweighted countries. In the multivariate estimation, weekly currency returns are regressed on the (demeaned) percentage weight change $\Delta \bar{w}_{i}$ interacted with a time dummy $D_{t}$ that marks the event week around November 30,2001. The estimates of $\alpha_{1}$, the slope coefficient on $\Delta \bar{w}_{i} \times D_{t}$, are negative as in the equity market, but not significantly so. The negative slopes in the equity and currency markets suggest that speculators inaccurately estimated the amount of capital reallocated by index funds or the inventory accumulation of other speculators. If they overestimate the former or underestimate the later, then their aggregate trades may exceed the index funds' reallocations and lead to negative price effects. ${ }^{25}$ Excessive speculative behavior may be a pervasive problem in rare events such as announced global index changes where the scope for learning is limited.

The equity and currency effects on the second implementation date (May 31,2002 ) are presented in Table 8 . The slope estimates are once again negative in the equity market. In the currency market, in contrast, the Fisher and the multivariate estimates both indicate that exchange rate returns are positively associated with country weight changes. The null hypothesis of no association is rejected at the $1 \%$ significance level by the Fisher test and by the multivariate regression for the twelve-day window. The disconnect between the two markets-upweighted stocks do earn negative returns while upweighted currencies earn positive returns - suggests that local and global speculators are behaving differently. Indeed, a negative equity effect on the one hand points to large speculative equity positions being unwound, thereby offsetting index funds' equity reallocations. The positive exchange rate effect, on the other hand, indicates that no such unwinding is taking place in the currency market. It is plausible that local speculators are off-loading their positions while global speculators are not, perhaps because they have already done so on the first implementation date (when no currency effect was found). According to this scenario, global index funds' purchases of upweighted stocks are offset in the equity market by local arbitrageurs' sales but their purchases of upweighted currencies are not, leading to an appreciation of upweighted currencies but no appreciation of upweighted stocks.

To summarize, we find in line with the literature that gains made on upweighted stocks and upweighted currencies upon announcement are partially reversed upon implementation. These reversals can be interpreted as signs of expectational errors or coordination failures among speculators. Indeed, they face

25 Witness to this daunting problem is the declaration of Peter Lockyer, head of risk management at Merrill Lynch Investment Managers: "It will be very interesting to see exactly what happens. Active fund managers, passive fund managers and hedge funds will all want to benefit from these changes at others' expense. This means having to second-guess when and what these other investors will do. The effect may be to push certain key stocks in an unexpected direction." (Financial Times, May 17, 2001). 
Table 8

Stock and exchange returns around the second implementation of the MSCI index redefinition (May 31, 2002)

Panel A: Individual stock returns in local currency

$\Delta r_{i j}=\alpha_{0}+\alpha_{1} \Delta w_{i j}+\mu_{i j}$

\begin{tabular}{|c|c|c|c|c|c|c|}
\hline \multirow[b]{2}{*}{ Window size } & \multicolumn{2}{|c|}{$\begin{array}{l}\text { Raw returns } \\
\text { OLS }\end{array}$} & \multicolumn{2}{|c|}{$\begin{array}{l}\text { Raw returns } \\
\text { OLS clustered }\end{array}$} & \multicolumn{2}{|c|}{$\begin{array}{l}\text { Abnormal returns } \\
\text { OLS clustered }\end{array}$} \\
\hline & $\begin{array}{l}\text { (1) } \\
\text { 6 Days }\end{array}$ & $\begin{array}{c}(2) \\
12 \text { Days }\end{array}$ & $\begin{array}{l}\text { (3) } \\
6 \text { Days }\end{array}$ & $\begin{array}{c}\text { (4) } \\
12 \text { Days }\end{array}$ & $\begin{array}{l}(5) \\
6 \text { Days }\end{array}$ & $\begin{array}{c}\text { (6) } \\
12 \text { Days }\end{array}$ \\
\hline Constant & $\begin{array}{c}-1.992^{* * *} \\
(0.114)\end{array}$ & $\begin{array}{c}-3.152^{* * * *} \\
(0.176)\end{array}$ & $\begin{array}{c}-1.992^{* * *} \\
(0.408)\end{array}$ & $\begin{array}{c}-3.152^{* * *} \\
(0.667)\end{array}$ & $\begin{array}{c}-0.641^{* *} \\
(0.271)\end{array}$ & $\begin{array}{r}-0.846^{*} \\
(0.421)\end{array}$ \\
\hline$\Delta w_{i j}$ & $\begin{array}{l}-0.221^{* *} \\
(0.098)\end{array}$ & $\begin{array}{l}-0.827^{* * * *} \\
(0.160)\end{array}$ & $\begin{array}{c}-0.221 \\
(0.196)\end{array}$ & $\begin{array}{c}-0.827^{* *} \\
(0.347)\end{array}$ & $\begin{array}{c}-0.180 \\
(0.116)\end{array}$ & $\begin{array}{l}-0.788^{* * *} \\
(0.197)\end{array}$ \\
\hline $\begin{array}{l}\text { Obs. } \\
R^{2}\end{array}$ & $\begin{array}{l}2434 \\
0.0021\end{array}$ & $\begin{array}{l}2434 \\
0.0123\end{array}$ & $\begin{array}{l}2434 \\
0.0021\end{array}$ & $\begin{array}{l}2434 \\
0.0123\end{array}$ & $\begin{array}{l}2362 \\
0.0016\end{array}$ & $\begin{array}{l}2362 \\
0.0132\end{array}$ \\
\hline
\end{tabular}

Panel B: Exchange rate returns

\begin{tabular}{|c|c|c|c|c|c|}
\hline \multicolumn{3}{|c|}{ Nonparametric Fisher test } & \multicolumn{3}{|c|}{$\begin{array}{c}\text { Weekly currency returns regressions } \\
\Delta e_{i t}=\alpha_{0}+\alpha_{1} D_{t}+\alpha_{2}\left(\Delta \bar{w}_{i} \times D_{t}\right)+\mu_{i t},\end{array}$} \\
\hline Window size & 6 Days & 12 Days & Window size & 6 Days & 12 Days \\
\hline $\begin{array}{l}\text { Two-sided } \\
p \text {-value } \\
\text { One-sided } \\
p \text {-value }\end{array}$ & 0.005 & 0.038 & $\begin{array}{c}D_{t} \\
\Delta \bar{w}_{i} \times D_{t}\end{array}$ & $\begin{array}{c}0.086 \\
(0.081) \\
0.107 \\
(0.100)\end{array}$ & $\begin{array}{l}0.067 \\
(0.057) \\
0.203^{* * *} \\
(0.071)\end{array}$ \\
\hline Obs. & 33 & 33 & $\begin{array}{l}\text { Currency obs } \\
\text { Time obs. }\end{array}$ & $\begin{array}{c}33 \\
980\end{array}$ & $\begin{array}{c}33 \\
986\end{array}$ \\
\hline
\end{tabular}

We analyze individual stock returns (Panel A) and exchange returns (Panel B) around the second implementation of the MSCI index redefinition. The index adjusted the remaining 50\% toward the new index on May 31, 2002 (the index adjusted the first $50 \%$ on November 30, 2001). See Table 2 for details on the individual stock return regressions. See Table 3 for details on the nonparametric Fisher test carried out on exchange rates, and Table 6 for details on the regressions on daily currency returns. The currency return regressions in Panel B use the scaled (and demeaned) weight change $\Delta \bar{w}_{i}$ with the scaling factor $S F_{i}=\frac{1}{2}\left(w_{i}^{n}+w_{i}^{o}\right)$ interacted with a time dummy $D_{t}$ marking alternatively a 6- or 12-trading-day event window around May 31, 2002. Standard errors for correlated panels accounting for a general covariance structure across all currencies are reported in parentheses. We indicate by ${ }^{*},{ }^{* *}$, and ${ }^{* * *}$ significance at the $5 \%, 3 \%$, and $1 \%$ level, respectively.

the daunting problem of having to forecast both the capital flows by index funds and the contrarian positions of other speculators. Moreover, the contrasting outcomes across the two markets, in particular on the second implementation date, suggest that local and global speculators follow different strategies. It appears that global arbitrageurs, unlike local arbitrageurs, unwound their position on the first implementation date.

\section{Discussion}

\subsection{Currency comovement}

The literature on equity index changes finds that stocks added to an index tend to comove more with this index (e.g., Barberis, Shleifer, and Wurgler 2005). We investigate here whether the same is true of currencies (i.e., whether 
upweighted [downweighted] currencies tend to comove more [less] with the other currencies in the MSCI index).

To test this prediction, we apply the methodology developed by Barberis, Shleifer, and Wurgler (2005). We construct a currency index, representing the average return on a basket of currencies. We measure both the equally weighted and the value-weighted return on the basket, where the weights in the latter case equal the MSCI country weights. We evaluate currencies' correlation with the basket by regressing the daily return on a currency $i$ on the daily basket return. A positive slope coefficient reflects the fact that currencies tend to fluctuate together. To avoid spurious effects, we remove the contribution of currency $i$ to the basket. This implies that the basket always consists of all currencies except the U.S. dollar and the currency that is the dependent variable.

We use daily data on exchange rates covering two-year periods before and after the announcement event (1998-1999 and 2003-2004), and test whether currencies' correlation with the basket has changed. We run the following panel regression:

$$
\begin{aligned}
\Delta e_{i t}= & \alpha_{0}+\alpha_{1} \text { Basket }_{t}+\alpha_{2} \Delta \bar{w}_{i}+\alpha_{3} D_{t}+\alpha_{4}\left(\Delta \bar{w}_{i} \times \text { Basket }_{t}\right) \\
& +\alpha_{5}\left(D_{t} \times \text { Basket }_{t}\right)+\alpha_{6}\left(D_{t} \times \Delta \bar{w}_{i}\right) \\
& +\alpha_{7}\left(\Delta \bar{w}_{i} \times \text { Basket }_{t} \times D_{t}\right)+\varepsilon_{i t},
\end{aligned}
$$

where $\Delta e_{i t}$ measures the percentage change in the currency $i$ on day $t$, Basket $_{t}$ is the return on our constructed index on day $t$ (equally or value weighted), $\Delta \bar{w}_{i}$ is the weight change for currency $i$, and $D_{t}$ is a dummy variable that equals 0 in the pre-event period (1998-1999) and 1 in the post-event period (2003-2004). The coefficient of interest is $\alpha_{7}$, which multiplies $\Delta \bar{w}_{i} \times$ Basket $_{t} \times D_{t}$. A positive coefficient estimate indicates that upweighted currencies comove more with the basket in the post-event period, as expected. We estimate Equation (2) as a pooled regression with robust standard errors, clustered by both country and date, as well as a panel regression with errors that are correlated across panels.

The results are reported in Table 9. Panel A uses an equally weighted basket, while panel $\mathrm{B}$ uses a value-weighted one. The results show a significantly positive value for $\alpha_{7}$, across the different specifications. This suggests that following the rebalancing, upweighted currencies tend to comove more with each other than downweighted currencies. The results are not only statistically significant, but also economically large. Indeed, the estimate for $\alpha_{7}$ is about as large as that for $\alpha_{4}$, the coefficient on the interaction between Basket ${ }_{t}$ and $\Delta \bar{w}_{i}$. This suggests that the magnitude of the comovement across currencies doubles in the post-event window relative to the pre-event window.

Interestingly, the estimates of $\alpha_{1}$ and $\alpha_{5}$ are statistically positive across specifications. The positive coefficient estimate on Basket $t_{t}, \alpha_{1}$, captures the commonality of shocks across currencies, but it could also reflect shocks to the U.S. dollar, which affect both the currency on the left-hand side and the basket ( since currencies are all denominated against the U.S. dollar). This commonality 
Table 9

Changes in currency comovements following the MSCI index redefinition

Panel A: Equally-weighted basket of currency returns

(1) (2) (3) (4) (5)

Error structure

Country custer Day custer Both clusters Prais-Winsten Country FE

\begin{tabular}{lcccccc}
\hline Basket $_{t}$ & $0.636^{* * *}$ & $0.636^{* * *}$ & $0.636^{* * *}$ & $0.636^{* * *}$ & $0.636^{* * *}$ & $0.636^{* * *}$ \\
$\Delta \bar{w}_{i}\left(\times 10^{-1}\right)$ & 0.032 & 0.103 & 0.032 & 0.103 & 0.010 & 0.032 \\
& $-0.004^{* *}$ & $-0.004^{*}$ & $-0.004^{*}$ & $-0.004^{*}$ & $-0.004^{*}$ & -0.004 \\
$D_{t}\left(\times 10^{-2}\right)$ & 0.002 & 0.002 & 0.002 & 0.002 & 0.002 & 0.000 \\
& -0.012 & -0.012 & $-0.012^{* *}$ & -0.012 & $-0.012^{* * *}$ & -0.012 \\
$\Delta \bar{w}_{i} \times$ Basket $_{t}$ & 0.009 & 0.011 & 0.006 & 0.008 & 0.004 & 0.009 \\
& $0.117^{*}$ & 0.117 & 0.117 & 0.117 & $0.117^{*}$ & $0.117^{*}$ \\
$D_{t} \times$ Basket $_{t}$ & 0.068 & 0.276 & 0.095 & 0.283 & 0.068 & 0.068 \\
& $0.223^{* * *}$ & 0.223 & $0.223^{* * *}$ & 0.223 & $0.223^{* * *}$ & $0.223^{* * *}$ \\
$D_{t} \times \Delta \bar{w}_{i}\left(\times 10^{-2}\right)$ & 0.038 & 0.134 & 0.059 & 0.141 & 0.014 & 0.038 \\
& 0.026 & 0.026 & 0.026 & 0.026 & 0.026 & 0.026 \\
$D_{t} \times \Delta \bar{w}_{i} \times$ Basket $_{t}$ & 0.025 & 0.028 & 0.031 & 0.033 & 0.030 & 0.026 \\
& $0.903^{* * *}$ & $0.903^{* *}$ & $0.903^{* * *}$ & $0.903^{* * *}$ & $0.903^{* * *}$ & $0.903^{* * *}$ \\
Currency obs. & 0.102 & 0.334 & 0.117 & 0.339 & 0.099 & 0.102 \\
Time obs. & 33 & 33 & 33 & 33 & 33 & 33 \\
$R^{2}$ & 1044 & 1044 & 1044 & 1044 & 1044 & 1044 \\
& 0.059 & 0.059 & 0.059 & 0.059 & 0.059 & 0.059
\end{tabular}

Panel B: Value-weighted basket of currency returns

\begin{tabular}{lcccccc}
\hline Basket $_{t}$ & $31.580^{* * *}$ & $31.580^{* * *}$ & $31.580^{* * *}$ & $31.580^{* * *}$ & $31.580^{* * *}$ & $31.580^{* * *}$ \\
& 2.064 & 5.117 & 2.310 & 5.221 & 0.952 & 2.063 \\
$\Delta \bar{w}_{i}\left(\times 10^{-1}\right)$ & $-0.004^{* *}$ & $-0.004^{* *}$ & $-0.004^{* *}$ & -0.004 & $-0.004^{* *}$ & -0.004 \\
& 0.002 & 0.002 & 0.002 & 0.000 & 0.002 & 0.000 \\
$D_{t}\left(\times 10^{-2}\right)$ & $-0.025^{* * *}$ & $-0.025^{* * *}$ & $-0.025^{* *}$ & $-0.025^{* *}$ & $-0.025^{* * *}$ & $-0.025^{* * *}$ \\
& 0.009 & 0.011 & 0.011 & 0.012 & 0.008 & 0.009 \\
$\Delta \bar{w}_{i} \times$ Basket $_{t}$ & $25.338^{* * *}$ & 25.338 & $25.338^{* * *}$ & $25.338^{*}$ & $25.338^{* * *}$ & $25.338^{* * *}$ \\
& 35.850 & 15.030 & 4.259 & 15.145 & 3.022 & 3.842 \\
$D_{t} \times$ Basket $_{t}$ & $10.261^{* * *}$ & $10.261^{* *}$ & $10.261^{* * *}$ & $10.261^{* *}$ & $10.261^{* * *}$ & $10.261^{* * *}$ \\
$D_{t} \times \Delta \bar{w}_{i}\left(\times 10^{-2}\right)$ & 2.250 & 4.627 & 2.476 & 4.741 & 1.291 & 2.250 \\
& 0.0268 & 0.0268 & 0.0268 & 0.0268 & 0.0268 & 0.0268 \\
$D_{t} \times \Delta \bar{w}_{i} \times$ Basket $_{t}$ & 0.0252 & 0.0266 & 0.0256 & 0.0269 & 0.0244 & 0.0252 \\
& $29.522^{* * *}$ & $29.522^{* *}$ & $29.522^{* * *}$ & $29.522^{* * *}$ & $29.522^{* * *}$ & $29.522^{* * *}$ \\
Currency obs. & 5.015 & 11.148 & 5.123 & 11.197 & 4.158 & 5.007 \\
Time obs. & 33 & 33 & 33 & 33 & 33 & 33 \\
$R^{2}$ & 1044 & 1044 & 1044 & 1044 & 1044 & 1044 \\
& 0.058 & 0.058 & 0.058 & 0.058 & 0.058 & 0.058 \\
\hline
\end{tabular}

This table examines whether currencies that are upweighted (downweighted) commove more (less) with the other currencies in the index. Daily data on exchange rates covering two-year periods before and after the announcement event (1998-1999 and 2003-2004) are used to estimate the following panel regression:

$$
\begin{aligned}
\Delta e_{i t}= & \alpha_{0}+\alpha_{1} \text { Basket }_{t}+\alpha_{2} \Delta \bar{w}_{i}+\alpha_{3} D_{t}+\alpha_{4}\left(\Delta \bar{w}_{i} \times \text { Basket }_{t}\right) \\
& +\alpha_{5}\left(D_{t} \times \text { Basket }_{t}\right)+\alpha_{6}\left(D_{t} \times \Delta \bar{w}_{i}\right)+\alpha_{7}\left(D_{t} \times \Delta \bar{w}_{i} \times \text { Basket }_{t}\right)+\varepsilon_{i t},
\end{aligned}
$$

where $\Delta e_{i t}$ measures the percentage change in the currency $i$ on day $t$, Basket $_{t}$ is the return on a constructed index of currencies on day $t$ (equally or value weighted), $\Delta \bar{w}_{i}$ represents the scaled weight change defined as the (demeaned) ratio of the weight change $w_{i}^{n}-w_{i}^{o}$ of currency $i$ and the scaling factor $S F_{i}=\frac{1}{2}\left(w_{i}^{n}+w_{i}^{o}\right)$, $D_{t}$ is a dummy variable that equals 0 in the pre-event period (1998-1999) and 1 in the post-event period (20032004). Panel A shows the results based on the basket constructed as an equally weighed index of currency returns, while Panel B presents the results based on the basket constructed as a value-weighted index of currency returns. We report OLS coefficients for the pooled currency data and consider alternative specification based on different treatments of the errors. Column (1) presents standard errors corrected for heteroskedasticity using White's adjustment. Columns (2), (3), and (4) allow for additional error clustering by country, day and country, and day, respectively. In Column (5), the coefficients are estimated using a Prais-Winsten regression, which allows for serial correlation. Standard errors here are adjusted assuming the disturbances are heteroskedastic and contemporaneously correlated across panels. In Column (6) we estimate a panel with country fixed effects. We report the standard errors below the coefficients. ${ }^{* * *},{ }^{* *}$, and ${ }^{*}$ represent significance levels at $1 \%, 5 \%$, and $10 \%$, respectively. The constant term is not reported. The variable $\mathrm{D}_{t}$ has been divided by 100 . 
appears to have intensified in the post-event period, as indicated by the positive coefficient estimate on Basket B $_{t}, D_{t}$. That is, currencies comove more with the basket after the event, regardless of their reweighting. This may be the result of intensifying international capital flows, perhaps because more capital is benchmarked to the MSCI index now that it is free-float-adjusted.

The increased comovement between exchange rate returns $\Delta e_{i t}$ and the term $\Delta \bar{w}_{i} \times$ Basket $_{t}$ for the period December 2000 to December $2002\left(D_{t}=1\right)$ relative to the preceding two years $\left(D_{t}=0\right)$ can also be illustrated by a moving (constant) kernel regression. For a moving window $M W$ of one hundred and eighty days, we estimate the coefficient $\alpha_{3}$ as

$$
\Delta e_{i t}=\alpha_{0}+\alpha_{1} \text { Basket }_{t}+\alpha_{2} \Delta \bar{w}_{i}+\alpha_{3} \times \Delta \bar{w}_{i} \times \text { Basket }_{t}, \quad t \in M W,
$$

and plot the estimate $\hat{\alpha}_{3}$ against the mid-point of the window. Figure 8 illustrates the increase of the comovement coefficient $\hat{\alpha}_{3}$ in 2000. The vertical line marks the announcement date of the MSCI index change on December 1, 2000. The coefficient $\hat{\alpha}_{3}$ is persistently higher for the two-year period following the index change.

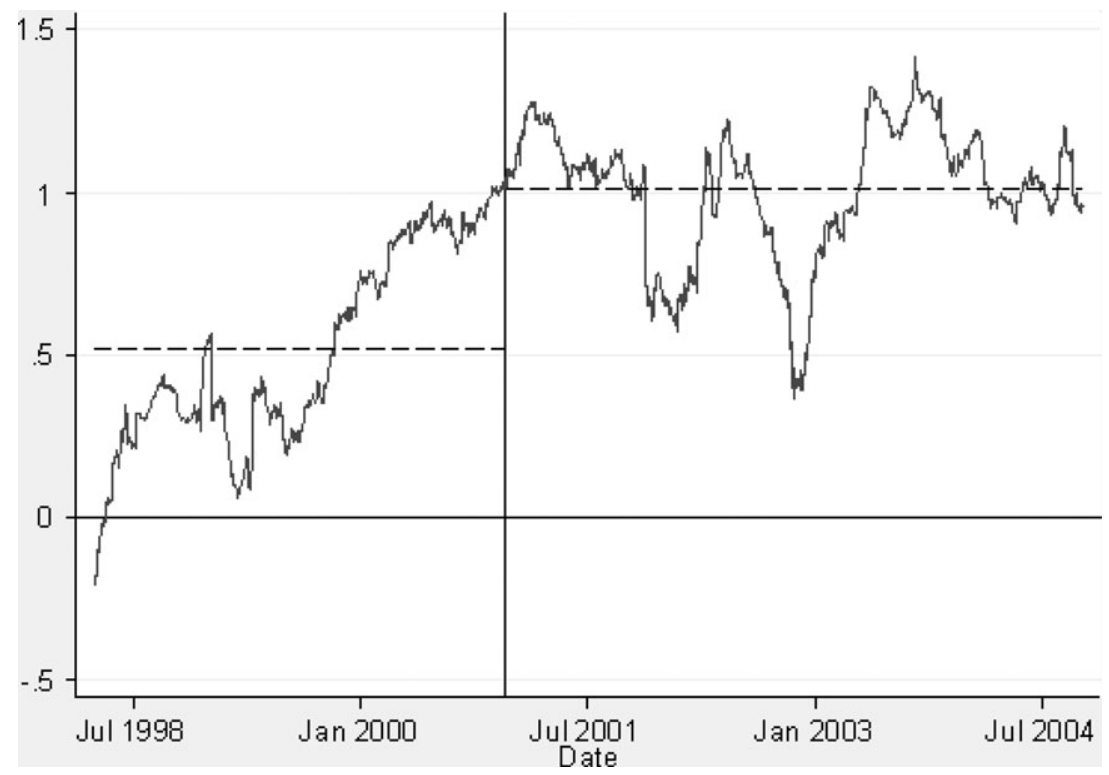

Figure 8

The graph plots the OLS regression coefficient $\hat{\alpha}_{3}$ of pooled exchange rate returns $\Delta e_{i t}$ on the interaction term $\Delta \bar{w}_{i} \times$ Basket $_{t}$ for a moving window of 180 days

The regression controls for the index percentage weight change of a country $\Delta \bar{w}_{i}$ and the return Basket $t_{t}$ of the currency basket. The comovement coefficient is plotted for the mid-point of the time window with equal weight on each observation. The vertical line marks the announcement of the MSCI index change on December 1, 2000. 


\subsection{Is the currency effect permanent?}

While our evidence shows that the index redefinition has an effect on the level of exchange rates that is both statistically and economically sizable in the short term, it is unclear whether or not it should persist. This ambiguity is also present in the literature on domestic index additions. While Harris and Gurel (1986) and Schleifer (1986) argue for a permanent effect, Beneish and Whaley (1996), and Lynch and Mendenhall (1997), examining S\&P 500 index changes that were announced before being implemented, find that the announcement effects are partially reversed on the following days. The literature on block trades also reports evidence of temporary price pressure on individual stocks conditional upon unusual demand or supply (Lakonishok, Shleifer, and Vishny 1991; Chan and Lakonishok 1993, 1995). In the international finance literature, Froot, O'Connell, and Seasholes (1998) find that local stock prices are sensitive to international investor flows, and that transitory inflows have a positive future impact on returns.

Since our analysis is based on short windows (from six or twelve days around each event for the return analysis, to two years for the comovement analysis), the effect may just be transitory and disappear after a few years. Here, we share the methodological limitations encountered by the articles that study the equity impact of index changes. Any long-term conclusion requires an estimation window so long that the ability of the standard event methodology to pin down changes in a statistically meaningful way is hampered. Indeed, other confounding effects may alter the relationship, and the underlying assumption of a constant stock (currency) sensitivity to index weight changes is less accurate. However, within the limited two-year window, the results clearly point in the direction of an increased comovement.

From a theoretical perspective, any discussion of the persistence of the exchange rate effect is still more complicated. According to the standard theory of money, exchange rates are a function of the relative supply of and demand for money. Any theoretical conclusion within a monetary framework depends on whether index changes modify the relative money demand temporarily or permanently. Arguments in favor of both hypotheses can be made. The reallocation of the index capital itself represents a one-time surge in the relative money demand for the upweighted country. But if a higher index representation leads to permanently higher relative asset turnover and generates related cash positions, changes in the money demand might be of a permanent nature. ${ }^{26}$ In light of this theoretical ambiguity, we refrain from making any predictions about the long-term behavior of exchange rates. But their short-term reaction

26 Moreover, the monetary authorities might respond to any change in the (permanent) relative money demand. If the central bank is concerned about asset price inflation or the price increase of imports, it may reduce the money supply and this reaction may potentially magnify the short-run exchange rate change. However, under any type of foreign currency peg, the central bank may respond to the increased money demand by a corresponding increase in the money supply. The latter channel would neutralize the persistence of the exchange rate effect even if the money demand does increase permanently. The monetary regime of the country under consideration should therefore matter for the persistence of the exchange rate effect. 
to the index change shown in Figure 4 is still of a striking magnitude and is likely to have real effects.

The evidence of a downward sloping demand curve for currencies presents evidence for international market segmentation. Assets denominated in different currencies are imperfect substitutes. Therefore, even uninformative equity flows as those resulting from an index revision result in an exchange rate adjustment. Such imperfect international asset substitutability is also supported by evidence on persistent violations of uncovered interest parity, which are the underlying source of the so-called carry trades. International arbitrage forces in the currency market appear too weak to maintain uncovered interest rate party. They also appear too weak to provide a flat currency supply curve to accommodate uninformative equity flows from an index revision.

\section{Conclusions}

The exchange rate reaction to exogenous capital flows has long been an open issue in international finance. Empirical work suffered from a lack of clear identification of capital flow shocks. At the same time, the growing quantitative importance of international equity flows has revived interest in the traditional portfolio channel of exchange rate determination. The MSCI Global Equity Index redefinition announced in December 2000 provides an ideal natural experiment to examine the impact of clearly exogenous equity flows on a large number of exchange rates. Moreover, because demand shocks clearly originate in the equity market, the redefinition offers the opportunity to test whether they are transmitted to the currency market.

We find that upweighted stocks and upweighted currencies earn large excess returns around the announcement of the index change. In other words, the global demand for stocks and the demand for currencies both slope down. Our results demonstrate that shocks to the equity market can propagate to the currency market. They also provide statistically and economically strong evidence that currencies - which form, by most accounts, the most liquid asset class - have a limited resilience. Our findings imply that foreign capital inflows may, in principle, cause exchange rate appreciations and current account deficits, as opposed to the reverse linkage underlying much of the macroeconomic literature.

References

Baker, M., and S. Savasoglu. 2002. Limited Arbitrage in Mergers and Acquisitions. Journal of Financial Economics 64:91-116.

Baker, M., J. Stein, and J. Wurgler. 2003. When Does the Market Matter? Stock Prices and the Investment of Equity-Dependent Firms. Quarterly Journal of Economics 118:969-1006.

Baker, M., and J. Wurgler. 2002. Market Timing and Capital Structure. Journal of Finance 57:1-32.

Barberis, N., and A. Shleifer. 2003. Style Investing. Journal of Financial Economics 68:161-99.

Barberis, N., A. Shleifer, and J. Wurgler. 2005. Comovement. Journal of Financial Economics 75:283-317. 
Beneish, M. D., and R. E. Whaley. 1996. An Anatomy of the "S\&P Game": The Effects of Changing the Rules. Journal of Finance 51:1909-30.

Boyer B. H. 2004. Style Investing and the Book-to-Market Factor. Working Paper, Brigham Young University.

Breedon, F., and P. Vitale. 2004. An Empirical Study of Liquidity and Information Effects of Order Flow on Exchange Rates. CEPR Discussion Papers, CEPR Discussion Papers: 4586.

Chakrabartia, R., W. Huang, N. Jayaramana, and J. Lee. 2005. Price and Volume Effects of Changes in MSCI Indices-Nature and Causes. Journal of Banking and Finance 29:1237-64.

Chan, L., and J. Lakonishok. 1993. Institutional Trades and Intraday Stock Price Behavior. Journal of Financial Economics 33:173-99.

1995. The Behavior of Stock Prices around Institutional Trades. Journal of Finance 50:1147-74.

Chen, H.-L. 2006. On Russell Index Reconstitution. Review of Quantitative Finance and Accounting 26:409-30.

Denis, D. K., J. J. McConnell, A. V. Ovtchinnikov, and Y. Yu. 2003. S\&P 500 Index Additions and Earnings Expectations. Journal of Finance 58:1821-40.

Dillon, U., and H. Johnson. 1991. Changes in the Standard and Poor's 500 List. Journal of Business 64:75-85.

Dominquez, K. 2003. When Do Central Bank Intervention Influence Intra-Daily and Longer-Term Exchange Rate Movements. Working Paper No. 9875, NBER.

Edison, H. J. 1993. The Effectiveness of Central Bank Intervention: A Survey of the Literature after 1982. Princeton Special Papers in International Economics, 18.

Evans, M. D., and R. K. Lyons. 2002a. Order Flows and Exchange Rate Dynamics. Journal of Political Economy 110:170-81.

52. 2002b. Time Varying Liquidity in Foreign Exchange Markets. Journal of Monetary Economics 49:10252002c. Informational Integration and FX Trading. Journal of International Money \& Finance 21:807-32.

Frankel, J. A. 1982. In Search of the Exchange Risk Premium: A Six-Currency Test Assuming Mean-Variance Optimization. Journal of International Money and Finance 1:255-74.

Froot, K., P. O'Connell, and M. Seasholes. 2001. The Portfolio Flows of International Investors. Journal of Financial Economics 59:151-93.

Froot, K., and T. Ramadorai. 2005. Currency Returns, Intrinsic Value, and Institutional Investor Flows. Journal of Finance 60:1535-66.

Garry, M., and W. N. Goetzmann. 1986. Does Delisting from the S\&P 500 Affect Stock Price? Financial Analysts Journal 42:64-69.

Goetzmann, W. N., and M. Massa. 2002. Index Funds and Stock Market Growth. Journal of Business 76:1-28.

Greenwood, R. 2005. Short- and Long-Term Demand Curves for Stocks: Theory and Evidence on the Dynamics of Arbitrage. Journal of Financial Economics 75:607-49.

Harris, L., and E. Gurel. 1986. Price and Volume Effects Associated with Changes in the S\&P 500: New Evidence for the Existence of Price Pressure. Journal of Finance 41:851-60.

Hau, H., W. Killeen, and M. Moore. 2002. How Has the Euro Changed the Foreign Exchange Market? Economic Policy 34:151-77.

Hau, H., and H. Rey. 2004. Can Portfolio Rebalancing Explain the Dynamics of Equity Returns, Equity Flows, and Exchange Rates. American Economic Review 96:126-33.

Hau, H., and H. Rey. Forthcoming. Exchange Rates, Equity Prices and Capital Flows. Review of Financial Studies. 
Hedge, S. P., and J. B. McDermott. 2003. The Liquidity Effects of Revisions to the S\&P500 Index: An Empirical Analysis. Journal of Financial Markets 6:413-59.

Kaul, A., V. Mehrotra, and R. Morck. 2000. Demand Curves for Stocks Do Slope Down: New Evidence from an Index Weights Adjustment. Journal of Finance 55:893-912.

Kouri, P. 1983. Balances of Payment and the Foreign Exchange Market: A Dynamic Partial Equilibrium Model. In J. Bhandri and B. Putnam (eds.), Economic Interdependence and Flexible Exchange Rates, pp. 85-104. Cambridge, MA: MIT Press.

Lakonishok, J., A. Shleifer, and R. W. Vishny. 1991. Do Institutional Investors Destabilize Stock Prices? Evidence on Herding and Feedback Trading. Working Paper No. 3846, NBER.

1992. The Impact of Institutional Trading on Stock Prices. Journal of Financial Economics 32:23-43.

Lynch, A. W., and R. R. Mendenhall. 1997. New Evidence on Stock Price Effects Associated with Changes in the S\&P 500 Index. Journal of Business 70:351-83.

Massa, M., X. Tong, and U. Peyer. 2004. Limits of Arbitrage and Corporate Financial Policy. Working Paper, CEPR 4829.

Menkhoff, L., and M. Taylor. 2007. The Obstinate Passion of Foreign Exchange Professionals: Technical Analysis. Journal of Economic Literature 45:936-73.

Onayev, Z. M., and V. M. Zdorovtsov. 2008. Predatory Trading around Russell Reconstitution. Working Paper, State Street Global Advisors.

Pavlova, A., and R. Rigobon. 2003. Asset Prices and Exchange Rates. Working Paper, MIT.

Payne, R., and P. Vitale. 2003. A Transaction Level Study of the Effects of Central Bank Intervention on Exchange Rates. Journal of International Economics 61:331-52.

Rogoff, K. 1984. On the Effect of Sterilized Intervention: An Analysis of Weekly Data. Journal of Monetary Economics 18:199-217.

Shleifer, A. 1986. Do Demand Curves for Stocks Slope Down? Journal of Finance 41:579-90.

Shleifer, A., and R. W. Vishny. 1997. The Limits of Arbitrage. Journal of Finance 52:35-55.

Siourounis, G. 2004. Capital Flows and Exchange Rates: An Empirical Analysis. Mimeo, London Business School.

Teo, M., and S. J. Woo. 2002. Style Effects. Unpublished Working Paper, Singapore Management University.

Warther, V. A. 1995. Aggregate Mutual Fund Flows and Security Returns. Journal of Financial Economics 39:209-35.

Wurgler, J., and E. Zhuravskaya. 2002. Does Arbitrage Flatten Demand Curves for Stocks? Journal of Business 75:583-608.

Zheng, L. 1999. Is Money Smart? A Study of Mutual Fund Investors' Fund Selection Ability. Journal of Finance 54:901-33. 